\title{
Environmental and economic impacts of fertilizer drawn forward osmosis
}

\section{and nanofiltration hybrid system}

Jung Eun Kim ${ }^{\mathrm{a}}$, Sherub Phuntsho ${ }^{\mathrm{a}^{*}}$, Laura Chekli ${ }^{\mathrm{a}}$, Seungkwan Hong ${ }^{\mathrm{b}}$, Noreddine Ghaffour ${ }^{\mathrm{c}}$, TorOve Leiknes ${ }^{\mathrm{c}}$, Joon Yong Choid ${ }^{\mathrm{d}}$, Ho Kyong Shon ${ }^{\mathrm{a}^{*}}$

a Centre for Technology in Water and Wastewater, School of Civil and Environmental Engineering, University of Technology, Sydney (UTS), Broadway, NSW 2007, Australia

b School of Civil, Environmental \& Architectural Engineering, Korea University, 1, 5-ka, Anam-Dong, Sungbuk-Gu, Seoul 136-713, Republic of Korea

${ }^{c}$ King Abdullah University of Science and Technology (KAUST), Water Desalination and Reuse Center (WDRC), Biological and Environmental Sciences \& Engineering Division (BESE), Thuwal, 23955-6900, Saudi Arabia

d Hyorim Industries Inc., Yatap-dong, Bundang-gu, Seongnam-city, 513-2, Gyeonggi-do, Republic of Korea

*Corresponding authors: Email: Hokyong.Shon-1@uts.edu.au; $\underline{\text { Sherub.Phuntsho@uts.edu.au }}$ 


\section{Graphical Abstract}

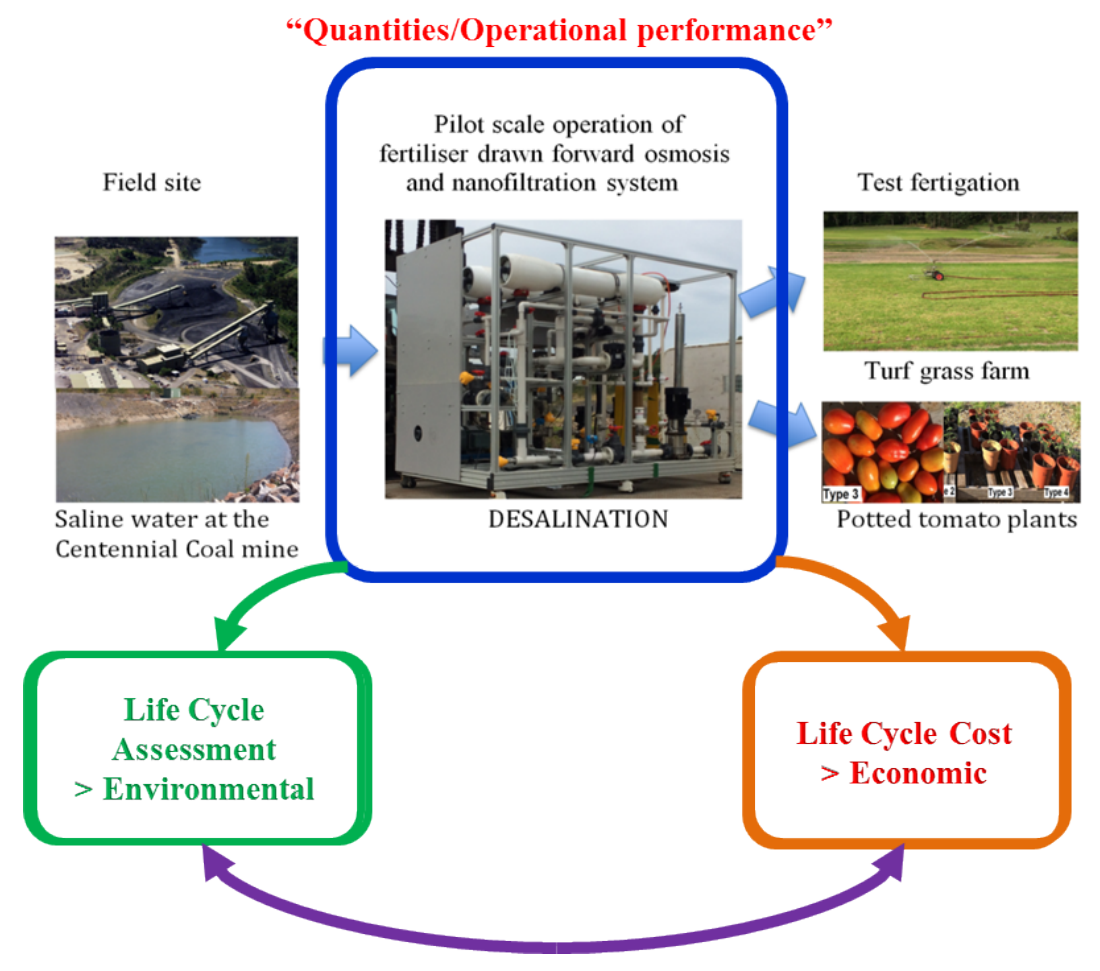




\section{Research highlights}

- Environmental impacts of the FDFO-NF(TFC) hybrid system can be lower than RO hybrid systems

- The FDFO-NF hybrid system consumes $21 \%$ less energy than the UF-RO hybrid system

- The unit OPEX cost of FDFO-NF (TFC) system is 14\% lower than UF-RO hybrid system

- Improving flux and lowering the cost of the CTA FO membrane can make the FDFO-NF cost effective 


\begin{abstract}
Environmental and economic impacts of the fertilizer drawn forward osmosis (FDFO) and nanofiltration (NF) hybrid system were conducted and compared with conventional reverse osmosis (RO) hybrid scenarios using microfiltration (MF) or ultrafiltration (UF) as a pre-treatment process. The results showed that the FDFO-NF hybrid system using thin film composite forward osmosis (TFC) FO membrane has less environmental impact than conventional RO hybrid systems due to lower consumption of energy and cleaning chemicals. The energy requirement for the treatment of mine impaired water by the FDFO-NF hybrid system was $1.08 \mathrm{kWh} / \mathrm{m}^{3}$, which is $13.6 \%$ less energy than an MF-RO and $21 \%$ less than UFRO under similar initial feed solution. In a closed-loop system, the FDFO-NF hybrid system using a TFC FO membrane with an optimum NF recovery rate of $84 \%$ had the lowest unit operating expenditure of AUD $\$ 0.41 / \mathrm{m}^{3}$. Besides, given the current relatively high price and low flux performance of the cellulose triacetate and TFC FO membranes, the FDFO-NF hybrid system still holds opportunities to reduce operating expenditure further. Optimizing NF recovery rates and improving the water flux of the membrane would decrease the unit OPEX costs, although the TFC FO membrane would be less sensitive to this effect.
\end{abstract}

Key words: Desalination; Fertiliser drawn forward osmosis; Life cycle assessment; Reverse osmosis; Nanofiltration; Fertigation; Hybrid systems 


\section{Introduction}

Agricultural sectors consume up to $60-75 \%$ of Australia's total fresh water, mainly in the form of irrigation to grow food [1]. However, the scarcity of fresh water is a major issue in many regions. During drought, the limited available fresh water is prioritized for domestic consumption, leaving agriculture among the most affected sectors. Creating new water resources, by recycling, desalinating and reusing water, for example, should be one of the strategies in a sustainable integrated water management plan.

Coal seam gas and underground coal mining activities produce large volumes of saline groundwater. Despite meeting progressively more stringent discharge standards, proper treatment, management and disposal remain a significant challenge for the coal industry [2]. Currently, this water is simply treated and disposed into the environment; however, with better treatment, mine impaired water could become a valuable resource for irrigation in dry regions or during the drought seasons. Salinity is the biggest obstacle to make this idea a viable commercial reality. Reverse osmosis (RO) is currently the most efficient desalination technology, but it is expensive and highly energy intensive, and this makes desalination for irrigation commercially unviable [3-5].

Among several recent innovations in desalination technologies, forward osmosis (FO) has emerged as a promising candidate for various applications, including irrigation [6]. Fertilizer drawn forward osmosis (FDFO), which uses fertilizers as its draw solution (DS), has shown potentially lower additional energy consumption and the diluted DS, containing fertilizer nutrients, can be used as non-potable water for the irrigation of crops [7].

In a recent study, Phuntsho, et al. [7] reported that although using the FDFO process alone would be ideal, the final dilution of the fertilizer DS is limited by its osmotic equilibrium with the feed salinity or osmotic pressure. When the feed has higher salinity, the concentration of the final diluted fertilizer is also correspondingly higher, and is greater than 
the concentration level generally required for direct irrigation [8]. Among several options studied, nanofiltration (NF) has been suggested as one of the most suitable post-treatment processes to reduce fertilizer concentration for direct fertigation, and an FDFO-NF hybrid system has recently been studied both in the laboratory and at pilot scale [9, 10].

The pilot study was carried out using a 1000-4000 L/d capacity FDFO-NF desalination system at Centennial Coal's Newstan colliery in Fassifern, New South Wales for six months [3]. The pilot-scale FDFO-NF process was composed of two spiral wound FO membrane modules and one spiral wound NF membrane module. Flow rates, pressures, and electrical conductivity meters were installed at both the inlet and outlet of the membrane module. All the sensors were connected to a computer and thus collecting the data automatically. Detailed information about the design and control of the FDFO-NF system are described in our previous studies $[11,12]$. This study revealed that the technology was robust with the potential to produce nutrient rich irrigation water to support the surrounding farming industry. However, FDFO-NF hybrid desalination is a new technology and, therefore environmental and economic life cycle assessment (LCA) is essential to understand its comparative advantages with existing desalination technologies such as RO hybrid systems.

The main objective of this work was, therefore, to conduct an environmental and economic LCA that compares the FDFO-NF hybrid system with two conventional RO hybrid systems in the desalination of mine impaired saline groundwater. It has to be acknowledged that for the economic life cycle assessment of the FDFO-NF hybrid process only operating expenditure (OPEX) was considered due to the system boundary limitation of the current LCA study. Conventional RO hybrid systems use microfiltration (MF) and ultrafiltration (UF) as a pre-treatment process and are termed here as MF-RO and UF-RO hybrid systems, respectively. To authors' knowledge, this study is the first to undertake a detailed 
environmental and economic analysis of the FDFO-NF hybrid process for irrigation through reuse of coal mine impaired water.

\section{Materials and methods}

\subsection{Life cycle assessment of hybrid desalination systems}

The LCA framework used for this study is described elsewhere [13-15]. A standard LCA generally consists of four stages; goal and scope definitions, life cycle inventory analysis (LCI), life cycle impact assessment, and interpretation. The first three stages are briefly described in this section. The last stage, interpretation, is discussed in Section 3.

Three hybrid desalination systems were chosen for comparison: MF-RO, UF-RO, and FDFO-NF. FDFO-NF is further divided into two groups, namely FDFO-NF (CTA) which uses cellulose triacetate (CTA) membrane and FDFO-NF (TFC) which uses a thin film composite (TFC) membrane for the forward osmosis process. Fig. 1 shows the system boundaries under which the LCA was carried out for the desalination of coal mine impaired water. It has to be acknowledged that the data obtained in our previous pilot-scale FDFO-NF hybrid system study was used as the basis for this LCA study. Nevertheless, there were some challenges to incorporate all the operating data for this LCA study. In fact, the main objective of the previous study was to prove technical feasibility of the FDFO-NF process including cleaning strategies for the desalination of saline water produced during coal mining activities. Therefore, the life cycle analysis of all the hybrid system was conducted by assuming and adopting full-scale operating conditions from the previous LCA studies $[13,14,16-18]$. The details will be discussed in Section 2.3. 


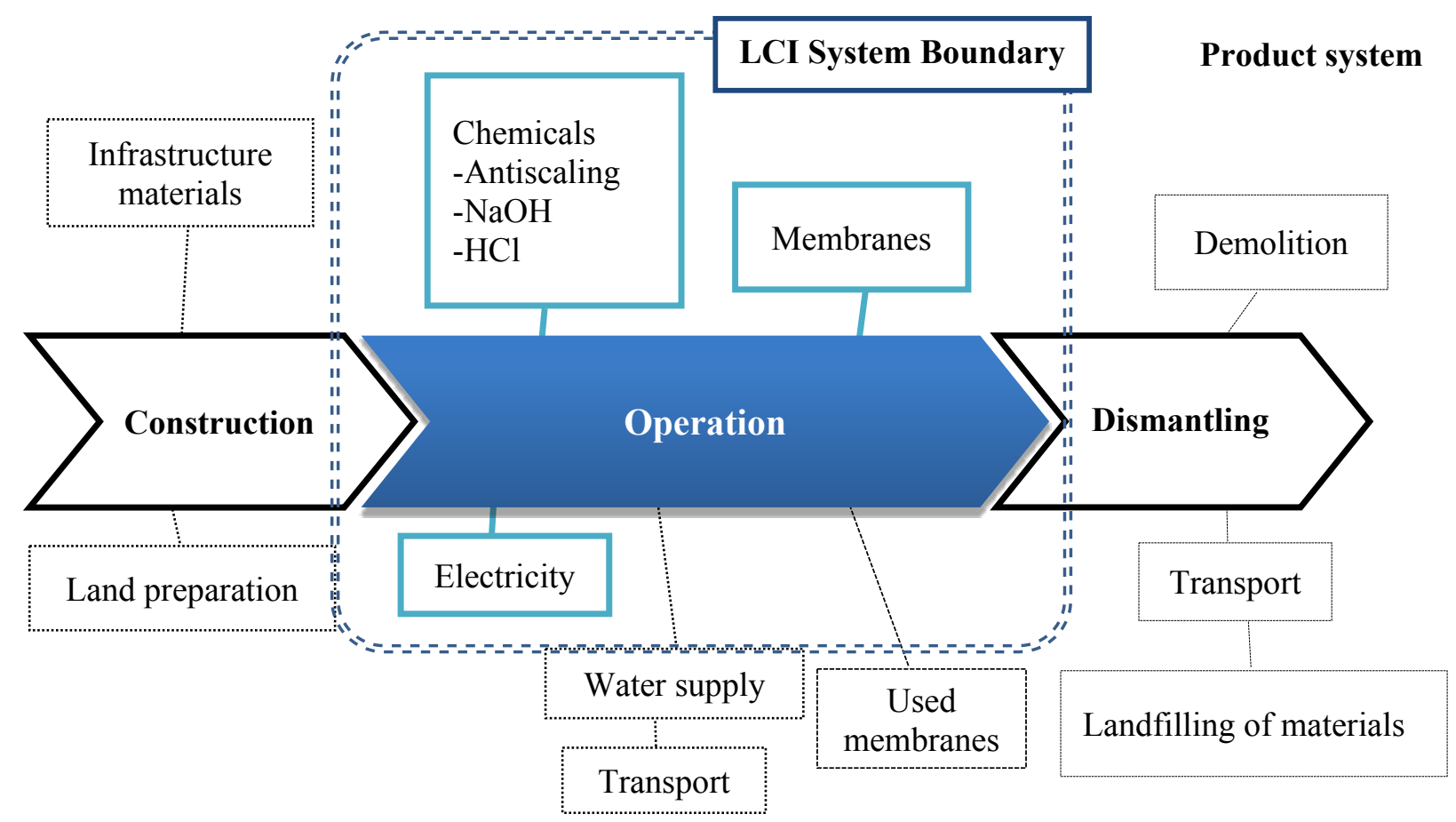

Fig. 1. Boundaries of the coal mine impaired water desalination system for all hybrid systems - life cycle inventory (LCI) for environmental and economic impact assessment.

\subsubsection{Life cycle inventory (LCI) analysis}

To collect the primary data for each hybrid system, an inventory analysis was carried out using the Ecoinvent LCA database version 3.0 and the Australian LCA database, Simapro version 8.1 [19-21]. Simapro LCA is one of the most widely used software tools. It includes impact assessment methods and several representative databases such as the Australian LCA database. Several common considerations for LCA for all hybrid systems are summarized as follows:

- In cases where no specific database for the production of materials and their quantities could be found in the Australian LCA database, information from the closest found database, Eco-invent, was used for the LCI.

- The types of materials used for MF, UF, NF and RO membranes applicable to this study and the total weight of materials for each membrane module were adopted from published literature [14, 22, 23]. 
- One of the most challenging parts of the operation phase is simplifying the membrane manufacturing procedure, including the consumption and production of the specific resources. All process data related to this procedure, including the covering membrane, spacer, membrane housing, collection tube, and glue, were available in previous studies $[13,14,17]$.

- The electricity production model is based on the Australian mix electricity data in the Simapro Australian LCI database. It consists of approximately $70 \%$ coal, $14 \%$ natural gas with remaining $16 \%$ derived from several sources, including renewable energy sources [18]. The cost of electricity was calculated at AUD $\$ 0.29 / \mathrm{kWh}$ in New South Wales, Australia [24].

- The LCA in the chemical phase is based on previous studies which include the most commonly used cleaning chemicals and scale inhibitors for each membrane process (UF, MF, RO, FO and NF). However the chemical transport component has been excluded, since transportation conditions are the same in all cases [25].

- It has to be noted that the feed water quality influences the fouling propensity. In this study, as shown in Table S1 in the Supplementary Information (SI), the concentration of the feed water was assumed to be $2,491 \mathrm{mg} / \mathrm{L}$ total dissolved solids ( $\approx 2,500 \mathrm{mg} / \mathrm{L} \mathrm{TDS})$. Based on this feed water quality, the frequency of chemical cleaning for RO hybrid systems for this study was adopted from $[13,26]$.

- Economic and environmental impacts of brine disposal may lead to different LCA results. However, as mentioned earlier, we conducted the pilot-scale FDFO-NF study at one of the coal mine site in Australia [3]. Since there is an available wastewater treatment plant (WTP) to treat mine impaired water, FO and RO brines as well as chemical cleaning wastewater can be directly transported to the WTP. For this reason, the current study did not consider the impacts of the brine and/or waste disposal on the LCA results. 
- The issues on forward and reverse salt flux and thus accumulation of ammonia and feed water constituents in the feed and draw solutions, respectively, could have significant environmental and economic impacts [3]. However, such issues were not considered in the current study as the scope of this study was first to evaluate comparative advantages of the FDFO-NF system, but the results obtained through the current study will be used as the basis for future comprehensive analyses.

- The construction and decommissioning phases of the plant were not accounted for this study due to its long life span, and given that similar conditions apply to all the three hybrid systems [25].

- The water quality for all hybrid systems was assumed based on the characterization of feed, diluted fertilizer, and final product water as shown in Table S1 in the SI, which was around 2,500 mg/L TDS, 7,600 mg/L TDS, and less than 1,000 mg/L TDS (irrigation purpose [3]), respectively.

- Plant capacity in the LCA was set for the production of $100,000 \mathrm{~m}^{3}$ of reusable water, and this figure was used for all hybrid systems. All materials and energy inputs were determined and normalized based on the functional unit [14]. Operational phase of life cycle inventories for all hybrid processes is therefore shown in Table S5 in the SI.

- The LCA study was conducted by focusing on the operational phases (i.e., chemical, membrane and energy consumption). The unit operating expenditure (OPEX, AUD $\$ / \mathrm{m}^{3}$ ) was calculated on an annual basis [13].

- Due to the system boundary limitation of the current study, the capital expenditure (CAPEX) was excluded from the current LCA study.

- Membrane costs were based on the market price for 8040 RO modules at AUD \$1,250 and 8040 NF modules at AUD \$1,160, respectively [27]. The cost of the FO module was 
assumed to be same as the RO module since it was recently demonstrated that cost of FO modules could be reduced in the future [28].

\subsubsection{Methodology of life cycle impact assessment}

Life cycle impact assessment (LCIA) is the third stage of the LCA. It aims at comparing the individual indicators calculated from the inventory analysis to contribute to the evaluation of the overall potential impacts of the system [29].

In this study, the environmental impact assessment was performed using the Australian indicator set v.3.01. This set includes six relevant impact assessment categories, as shown in Table S2 of the SI. They are global warming (GW), fossil fuel and mineral resource (FMR), eutrophication (EP), human toxicity (HT), ozone depletion (OD), and ecotoxicity (ET). Each category was assessed for the three most important operational components (Fig. 1): membranes, electricity, and chemicals.

In addition, the economic assessment considered the annual OPEX cost for three components: membrane replacement (MR), energy (EC), and membrane cleaning chemicals (CC). The operating costs for personnel were omitted on the assumption that they would be similar in all the cases. The OPEX data for the conventional RO and NF processes were calculated from secondary data (input data) from the literature $[26,30]$ and were adopted to estimate the total OPEX costs.

\subsection{Sensitivity analysis}

The reliability of LCA results is highly dependent on the chosen database due to a large number of input parameters. For instance, manufacturing membrane modules requires resources to produce membranes, spacers, housing, collection tubes and adhesives, and this information can vary significantly. These parameters affect the robustness of the 
environmental and economic LCA outcomes. For this reason, the input and output amounts for the FDFO-NF hybrid system within the life cycle inventory were evaluated and compared using a sensitivity analysis that focused on the FO membrane module average water flux $\left(\mathrm{Lm}^{-2} \mathrm{~h}^{-1}, \mathrm{LMH}\right)$ and the FO module cost variations. For the sensitivity analysis with different module average fluxes, the experimental flux data was adopted from the field study of the FDFO-NF process to demonstrate how performances of currently available FO membranes affect the LCA results and were then compared with other conditions including the newly developed FO membranes.

One of the most important parameters in the FDFO-NF hybrid system, especially in a closed-loop system, is the NF recovery rate because it relates to both NF energy consumption and the FO membrane replacement cost (i.e., FO process performance in terms of the average water flux). Performing NF at higher recovery rates increases the inlet DS concentration (osmotic driving force) and hence reduces the membrane area required; however, it also increases the operating cost (i.e., NF energy cost). Therefore, to make the FDFO-NF hybrid system cost effective, an optimum NF recovery rate is pivotal. Therefore, the sensitivity analysis on the NF process was also conducted at varying NF recovery rates in the closedloop FDFO-NF hybrid system.

The parameters used in the sensitivity analysis are summarized in Table 1. All equations are described in Table S3, and the input data are presented in Table S4 in the SI. 
Table 1 Parameters included in the sensitivity analysis.

Parameters varied for the sensitivity analysis Description of the change of parameter

1. Variation of the module average water flux $\left(\mathrm{J}_{\mathrm{w}}\right)$

- Experimental data - Long-term pilot operation of the FDFO process [3]

- $\mathrm{J}_{\mathrm{w}, \text { СTA-1 }}: 3 \mathrm{LMH}$ - $\mathrm{J}_{\mathrm{w}, \mathrm{TFC}-1}: 10 \mathrm{LMH}$

- Module-scale simulation using currently available FO flux modelling [31, 32] $]^{\mathrm{a}, \mathrm{b}}$

- $\mathrm{J}_{\mathrm{w}, \mathrm{CTA}-2}: 8 \mathrm{LMH}$

- $\mathrm{J}_{\mathrm{w}, \text { TFC-2}}: 20 \mathrm{LMH}$

- FO flux data adapted from literature

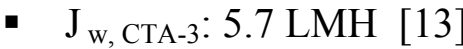

- $\mathrm{J}_{\mathrm{w}, \text { TFC-3 }}: 11 \mathrm{LMH}$ [31]

- Newly developed FO membranes [33]

- $\mathrm{J}_{\mathrm{w}, \mathrm{CTA}-4: 25 \mathrm{LMH}}$

- $\mathrm{J}_{\mathrm{w}, \text { TFC- } 4: 25 \mathrm{LMH}}$

2. FO module cost

- Assumption of FO module cost

- AUD \$200-1,500/module

3. Post-treatment process

- At all fixed conditions, only the NF recovery rate varied from $50 \%$ to $97 \%$

- NF process recovery rate under a continuous closed-loop FDFONF hybrid system using a simple massbalance relation.

${ }^{a}$ The parameter values used for FDFO process simulation using both FO membrane modules (CTA and TFC) are shown in Table S4 in the SI.

${ }^{\mathrm{b}}$ Validation of experimental water flux and predicted water flux is shown in the SI (Fig. S1, Tables S3 and S4).

\subsection{Hybrid process design conditions}

\subsubsection{Conventional RO hybrid desalination processes}

Fig. 2 shows the schematic layout for the MF-RO and UF-RO hybrid systems. The input data is presented in Table 2. The RO process was assumed to achieve $75 \%$ water recovery in both MF-RO and UF-RO given the relatively low TDS of the brackish feed water (TDS $1,000 \sim 10,000 \mathrm{mg} / \mathrm{L}$ ) [34]. It is worth noting here that, the performance simulation of the MF-RO and UF-RO hybrid systems was conducted to treat a feed water with TDS of 2,491 $\mathrm{mg} / \mathrm{L}$ with an osmotic pressure of 1.66 bar (see Table S1 in the SI). Due to this relatively low feed water concentration, it can be expected that the energy consumption of the MF-RO and UF-RO systems would be much lower than the conventional seawater treatment processes (i.e., 35,000 $\mathrm{mg} / \mathrm{L}$ TDS). In addition, the specific data inventory of the operation stage for MF-RO and UF-RO were simulated using the membrane manufacturer specifications and ROSA software (Version 9.1, Filmtech Dow Chemicals, USA). The energy consumption and system design of the unit processes for each hybrid system were 
calculated from the known principles of hydraulic flow $[14,35,36]$. The specific energy consumption $\left(\mathrm{SEC}\right.$ in $\mathrm{kWh} / \mathrm{m}^{3}$ ) for each hybrid system was estimated from the feed pumping energy for all processes (MF, UF, and RO), backwashing for MF and UF and chemical cleaning processes for RO and NF, as presented in Table 2.

\subsubsection{FDFO-NF hybrid desalination process}

Fig. 2 and Table 2 show the process layout diagram and the details of the hybrid FDFO-NF process. The FDFO-NF hybrid desalination process is fully described in Kim,et al. [37]. The 8040 FO membrane module average water flux data in Table 2 was derived from the long-term operational performance of the FDFO-NF hybrid system in our recent study [3], where two main advantages of the FDFO-NF hybrid process were observed. Flux decline caused by membrane fouling can be fully recovered simply by hydraulic or physical cleaning. This indicates that the FDFO process requires significantly low or no chemical cleaning, unlike other pressure-based membrane processes. Due to the high water quality obtained from the FDFO process (FO acts as pre-treatment to NF), chemical cleaning in the NF process can be significantly lowered in comparison to the RO process in MF-RO and UF-RO hybrid systems. It has to be understood here that the concentration of the diluted DS in the FDFO plays a significant role in NF energy consumption. The diluted fertilizer DS concentration before NF post-treatment was 7,600 mg/L with an osmotic pressure of 3.64 bar (see Table S1 in the SI). Such concentration refers to brackish ground water quality as mentioned above. The operating conditions for the NF post-treatment would be similar to a low-pressure RO post-treatment process for treating relatively low concentrated brackish groundwater [17]. 
(a) MF-RO hybrid system

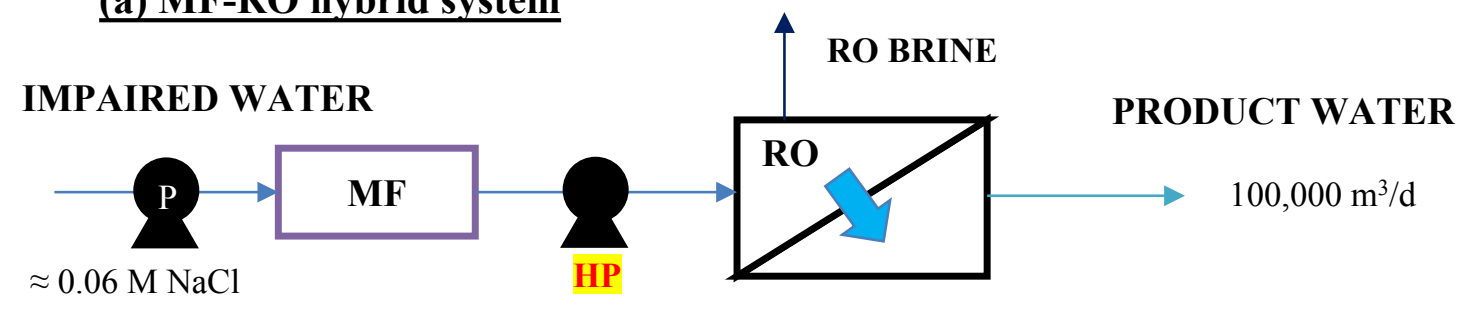

(b) UF-RO hybrid system

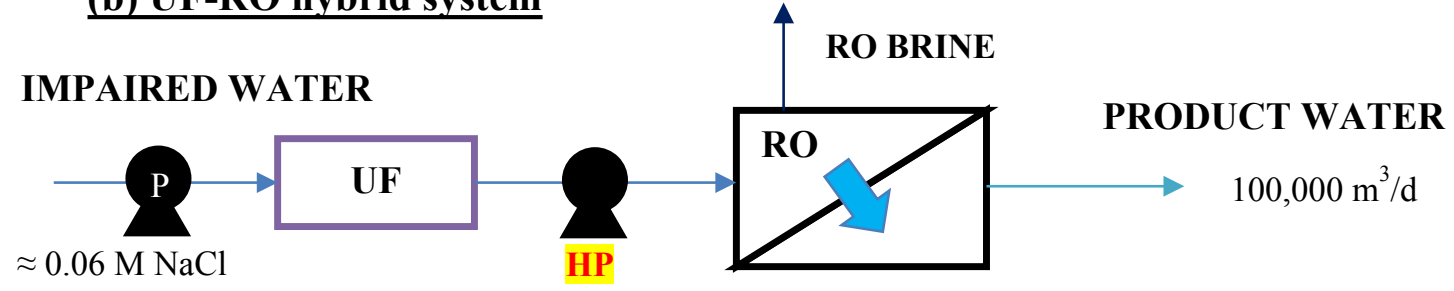

(c) FDFO-NF hybrid system

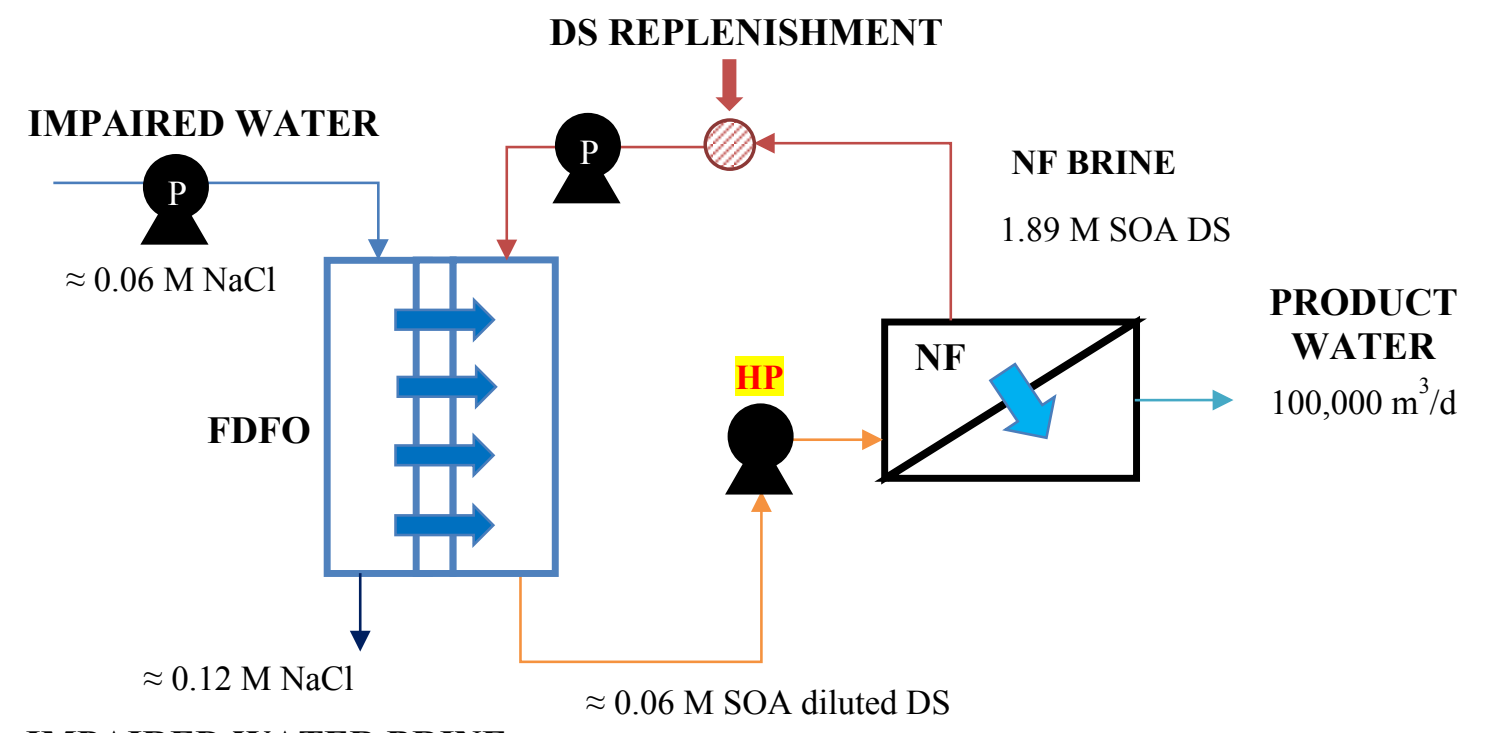

IMPAIRED WATER BRINE

Fig. 2. Schematic diagram of hybrid desalination systems of (a) MF-RO (b) UF-RO and (c) FDFO-NF. N.B. P: Pump and HP: High pressure pump. 
Table 2 The hybrid process design conditions used in this study and the process simulation results.

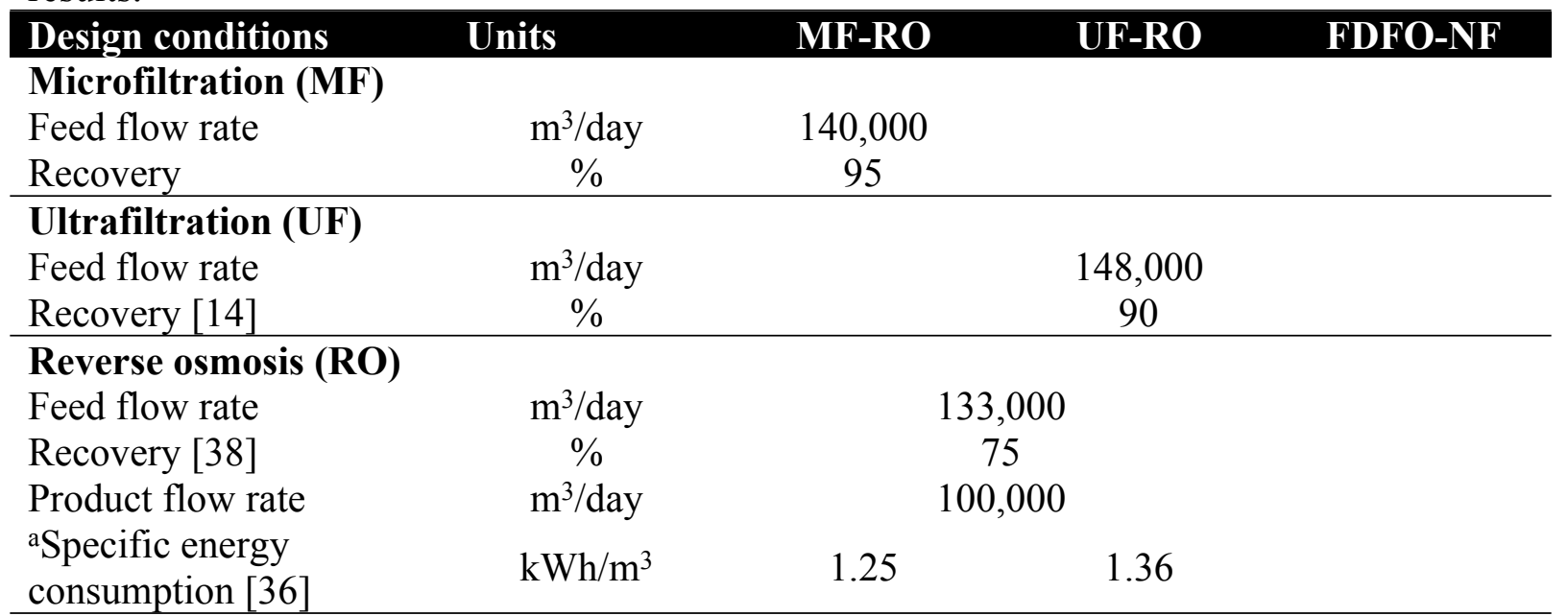

\section{Fertilizer drawn forward osmosis (FDFO)}

Feed water: mine impaired water $\approx 0.06 \mathrm{M} \mathrm{NaCl}$

Draw solution: 1.89 M Ammonium sulphate [3]

FS flow rate

DS flow rate

Recovery [32]

Average flux $\left(\mathrm{J}_{\mathrm{w}, \mathrm{CTA}}\right)^{*}$

$\mathrm{m}^{3} /$ day

220,000

$\mathrm{m}^{3} /$ day

43,000

$\%$

46

$\mathrm{LMH}$

3

$\mathrm{LMH}$

10

Average flux $\left(\mathrm{J}_{\mathrm{w}, \mathrm{TFC}}\right)^{*}$

$\mathrm{m}^{3 / \text { day }}$

100,000

Nano-filtration (NF)

${ }^{b}$ Final diluted fertilizer DS: 0.06 M Ammonium sulphate [3]

Diluted DS flow rate

(NF feed)

Recovery [39]

$\mathrm{m}^{3} /$ day

143,000

Product flow rate

$\%$

70

aSpecific energy

consumption [36, 39]

$\mathrm{m}^{3} /$ day

100,000

${ }^{a}$ Specific energy consumption was calculated using the equation adopted from [36] and ROSA.

${ }^{\mathrm{b}} \mathrm{NF}$ feed concentration refers to the concentration of the final diluted draw solution in the FDFO process. ${ }^{*} \mathrm{CTA}$ and TFC FO module area refers to 11.2 and $15.3 \mathrm{~m}^{2}$, respectively and the flux data is based on the field operation results.

\section{Results and discussion}

\subsection{Environmental impact assessment of desalination hybrid systems}

Identifying the most significant issues for each hybrid system is one of the main goals of an LCA interpretation phase. Fig. 3 presents the relative contribution analysis of the three hybrid systems for each of the six selected environmental impact categories obtained from the simulation input data presented in Table 2 (baseline input data). These results clearly show that electricity is one of the key factors in environmental impact for MF-RO and UF- 
RO hybrid systems. In fact, electricity consumption accounts for more than $70 \%$ of the total impact in all categories, except for ozone depletion (OD) where the contribution was about 30\%, as shown in Fig. 3 (a). Membranes account for less than $30 \%$, except in the OD category which is higher than $70 \%$, and chemicals account for less than $5 \%$ of the total impact in the MF-RO and UF-RO hybrid systems.

Fig. 3 (a) shows that, for the FDFO-NF hybrid system, both the membrane materials and the energy consumption play a major contribution to the environmental impact. It is worth noting that the contribution of the TFC FO membrane materials was significantly lower than the CTA membrane because its higher water flux requires less membrane modules. Membranes constituted $40-90 \%$ of the impact for the FDFO-NF (CTA) hybrid system in all six categories, with a maximum of $90 \%$ for OD. This is mainly due to the amount of raw materials needed to manufacture the membrane modules, including their chemical production [14]. The contribution of membranes decreased to $20-85 \%$ when TFC FO membranes were used, which indicates that a significant reduction in both environmental and economic impacts could be achieved by improving the performance of the FO membranes. Energy still accounts for more than $50 \%$ of the impact in most categories (except OD and human toxicity, HT), although this is much lower than the energy component of the RO hybrid systems.

Fig. 3 (b) compares the relative contributions of the four hybrid systems in the six environmental impact categories of the three main assessment areas: membranes, electricity, and chemicals. These results clearly show that the FDFO-NF hybrid system has a lower relative contribution to environmental impact in all six impact categories for energy and chemical consumption than the RO hybrid for irrigation purposes. However, Fig. 3 (b) also shows that the environmental impacts of the FDFO-NF membranes are significantly higher because the low water flux of FO membranes signifies that more membrane modules are required to achieve the same water production. Using a TFC FO membrane with improved 
water flux can reduce the environmental impacts of the membrane of about $20 \%$ and $40 \%$ to all impact categories compared to a CTA FO membrane.

It has to be noted that assumptions regarding the chemical cleaning process slightly differ from the previous studies $[14,23]$. In fact, chemical cleaning agents such as $\mathrm{NaOH}$, $\mathrm{HCl}$ and $\mathrm{NaOCl}$ as well as anti-scalant $\left(\mathrm{Na}_{5} \mathrm{P}_{3} \mathrm{O}_{10}\right)$ were assumed to be necessary for all membrane processes in the MF-RO and UF-RO hybrid systems. However, it was assumed (i.e. based on the results obtained in our long-term pilot-scale study) that the FDFO-NF system does not require chemical cleaning. Recent studies further demonstrated that physical cleaning was very efficient and easy to apply for practical FO operation $[12,40]$. Nevertheless, it is known that effective cleaning strategies for FO process should be determined by its applications because this affects the techno-economic assessment of the FO process. Since the FDFO-NF hybrid system in this study has a low fouling potential and fouling reversibility, the lower chemical cleaning frequency significantly reduces its environmental impact. In fact, the environmental impact does not include discharge of cleaning chemicals to the environment and hence the advantage of the FDFO-NF system may be even more significant. Conservative life cycle assessment of FO hybrid systems including chemical cleaning for the FO process could be one of the important areas of future studies for full-scale FO implementation. Additionally, $\mathrm{NaOH}$ and $\mathrm{HCl}$ were assumed to be necessary for the NF process, but at a much lower cleaning frequency than in normal operations [3]. Besides, the physical conditions for the cleaning process were assumed to be fixed, and the effects of cleaning time and cross-flow velocity on the cleaning efficiency were assumed to not be significant [41]. 


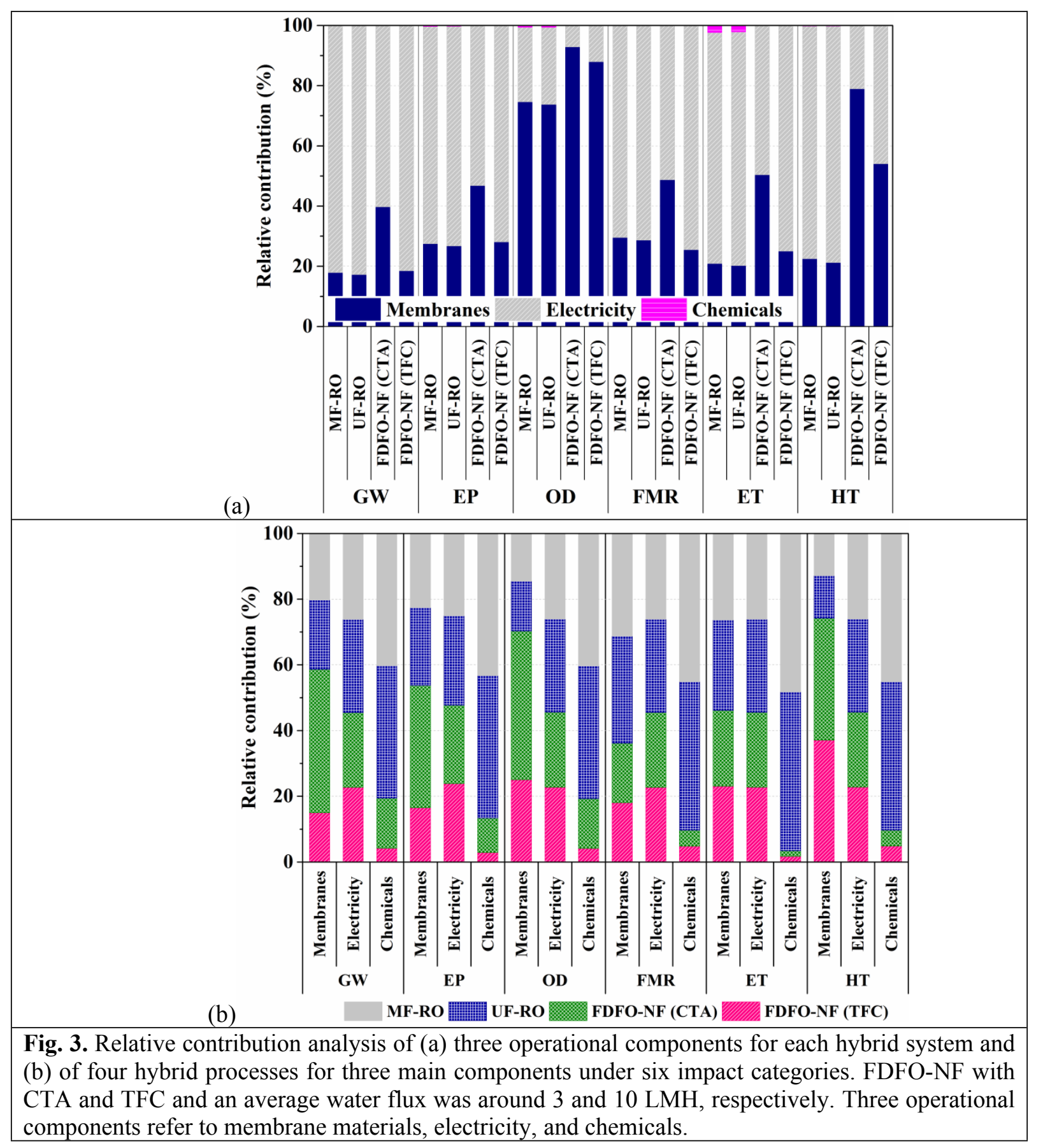

\subsection{Economic analysis: Operation expenditure (OPEX)}

The results presented in Fig. 4 show the total OPEX cost along with its major cost components for each hybrid system. Fig. 4 (a) shows that the total OPEX cost per unit volume of product water was the highest for the FDFO-NF (CTA) hybrid system with AUD $\$ 0.81 / \mathrm{m}^{3}$, compared to the MF-RO and UF-RO hybrid systems with AUD $\$ 0.49 / \mathrm{m}^{3}$ and AUD $\$ 0.54 / \mathrm{m}^{3}$, respectively. Based on these results, the FDFO-NF (CTA) desalination 
system does not appear to be an economically viable alternative for desalination compared to the existing RO hybrid technologies. However, the lowest total OPEX cost was obtained with the FDFO-NF (TFC) hybrid system at AUD $\$ 0.46 / \mathrm{m}^{3}$, indicating that the FDFO-NF hybrid system can be economically competitive if FO membranes with much higher water flux performances are used. This study, therefore, shows that using current TFC FO membranes, the unit OPEX cost of the product water from the FDFO-NF hybrid system is $5.3 \%$ lower than conventional MF-RO hybrid system and 14.3\% lower than UF-RO hybrid system.

Fig. 4 (a) clearly shows the advantages of the FDFO-NF hybrid system in terms of energy consumption. Table 2 shows that the total energy consumption of the FDFO-NF hybrid was $1.08 \mathrm{kWh} / \mathrm{m}^{3}$, which is $13.6 \%$ lower than that of MF-RO $\left(1.25 \mathrm{kWh} / \mathrm{m}^{3}\right)$ and $21 \%$ lower than that of the UF-RO $\left(1.36 \mathrm{kWh} / \mathrm{m}^{3}\right)$ hybrid system. Energy forms the major cost component of the RO hybrid systems, relatively contributing up to $83.1 \%$ of the total OPEX cost compared to FDFO-NF (CTA) and FDFO-NF (TFC) which is only about $40.5 \%$ and $71.8 \%$, respectively. It may be noted that this energy consumption does take into account the quality of irrigation water produced from each hybrid system as mentioned earlier (less than $1,000 \mathrm{mg} / \mathrm{L}$ based on the product water obtained during the field test of the FDFO-NF hybrid process) [3].

Fig. 4 (b) shows a detailed cost analysis for the FDFO-NF hybrid systems to highlight the contribution of each process (FO and NF) separately. These results clearly show that the FO contribution of the energy consumption to the total OPEX cost is not significant $(3.4 \%$ for CTA and $6.0 \%$ for TFC). However, FO membrane replacement costs contribute significantly to the OPEX cost with $55.1 \%$ for CTA and $21.4 \%$ for TFC. This indicates that the opportunity exists for the FDFO-NF hybrid system to further reduce OPEX costs by reducing the membrane replacement cost and the NF energy consumption. Previous studies $[4,14]$ have also pointed out that the overall environmental and economic impacts of FO membrane 
modules can be significantly reduced by improving the performance of FO membranes. The energy consumed by the NF process could also be reduced by operating the process at optimum recovery rates due to its flexibility on recovery rates [39]. The sensitivity analysis of the NF recovery rate will be discussed in the following section.

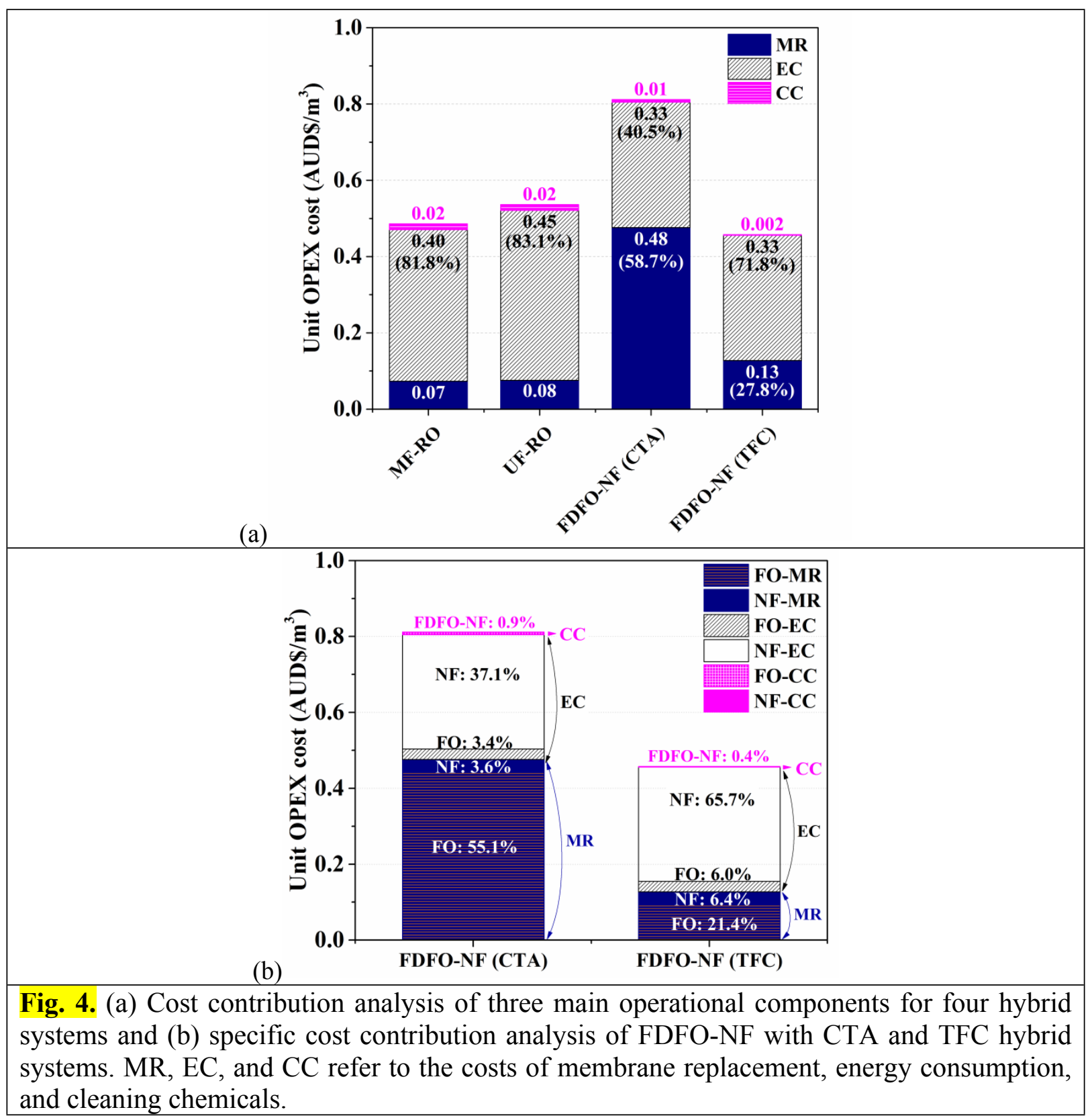

\subsection{Sensitivity analysis of the FDFO-NF hybrid system}


Electricity and the cost of replacing membranes are the two major contributing factors to the OPEX cost of the FDFO-NF hybrid system (see Fig. 4). A sensitivity analysis was undertaken to assess those components and identify opportunities to further reduce the OPEX costs. The key parameters are the cost of the module, the average water flux of the FO membrane, and the recovery rate of the NF process. All the analyses assumed a plant capacity of $100,000 \mathrm{~m}^{3} /$ day.

Logically, the two obvious ways to reduce membrane replacement costs are to reduce the cost of the membrane module or reduce the number of modules required. Cheaper modules may result from improvements in mass production, but the development of a market can take time. Reducing the number of modules can only come through drastic improvements in the average water flux of the whole FO membrane system, which contains several FO membrane modules connected in series. As the DS becomes more and more diluted along its length, water flux ultimately decreases. Hence, the average water flux is a significant parameter in estimating the number of membrane modules required, subsequently, their total replacement cost. Fig. 5 shows a sensitivity analysis of changes in module cost and average water flux. As expected, when the cost of a module decreases and the average water flux increases, the overall OPEX cost decreases for both FDFO-NF hybrid systems. However, membrane replacement costs are much higher in the FDFO-NF system, so the CTA and TFC membranes are discussed separately below.

Fig. 5 (a) shows the variations in the OPEX cost of the FDFO-NF (CTA) hybrid system with different 8040 CTA FO membrane costs and average water flux levels. At the cost of AUD \$1,250 per module with an average water flux of $3 \mathrm{LMH}$, the unit OPEX cost of irrigation water is AUD $\$ 0.81 / \mathrm{m}^{3}$. At this price, FDFO-NF (CTA) is not economically viable compared to existing MF-RO and UF-RO hybrid systems. However, when the average water flux exceeds $8 \mathrm{LMH}$, the membrane replacement cost is significantly reduced, and the OPEX 
cost per unit decreases below AUD $\$ 0.53 / \mathrm{m}^{3}$, which becomes cost effective. Achieving such a significant improvement in water flux may be a major challenge for CTA FO membranes, as they are generally reported to have lower water permeability than TFC FO membranes [42].

Lowering the cost of the CTA FO membrane module may be another way of reducing the OPEX cost of this system. At the same average water flux of $3 \mathrm{LMH}$, the FDFO-NF (CTA) hybrid system only becomes cost competitive when the cost of the CTA FO membrane module falls by at least $60 \%$ to AUD $\$ 500$ per module. This would only be likely if the CTA FO market share significantly improves in the future [17].

As presented earlier in Section 3.2, FDFO-NF (TFC) is already cost effective compared to the MF-RO and UF-RO hybrid systems. Fig. 5 (b) shows how the change in the cost of TFC FO membranes and average water flux affect the unit OPEX cost of irrigation water in the FDFO-NF (TFC) hybrid system. Unlike for the CTA FO membrane, variations in these parameters do not seem to have a significant impact. For example, improving the water flux from $10 \mathrm{LMH}$ to a threshold flux of $30 \mathrm{LMH}$ [4] is not likely to significantly reduce the OPEX cost of the FDFO-NF (TFC) hybrid system, where membrane replacement only account for $21.4 \%$ of the OPEX compared to $55.1 \%$ in for the FDFO-NF (CTA) hybrid system (Fig. 4 (b)). However, there is a potential to improve the module water flux, and this could play a more significant role in further lowering the environmental impact of the FDFONF (TFC) hybrid system. Recent publications have reported the fabrication of TFC FO membranes with a water flux at magnitudes 3 to 6 times higher than the CTA FO membrane [42-46]. Therefore, it is clear that opportunities to further improve the membrane and its performance exist, and this could make the FDFO-NF hybrid system more cost effective than MF-RO or UF-RO hybrid systems. 


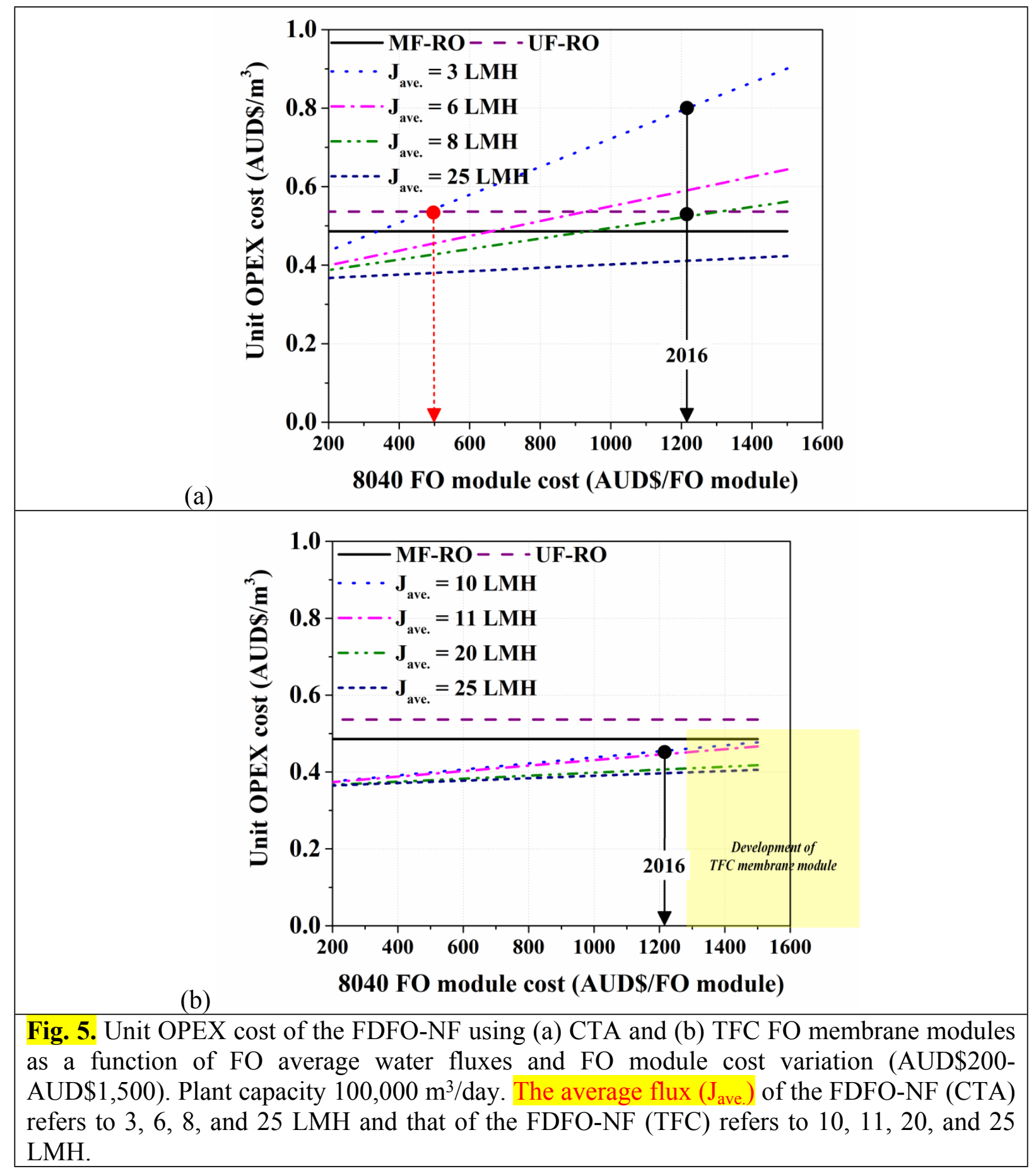

In a continuous closed-loop FDFO-NF hybrid system (see Fig. 2), the NF process is critical because it plays a significant role in both NF energy and FO membrane replacement costs [47]. Performing the NF process at a lower recovery rate decreases the driving force in the FO process (lower osmotic pressure of the DS) and increases FO membrane area requirement, but it also lowers energy consumption. Although the module average water flux 
can be increased by increasing the inlet DS concentration (i.e. increasing the NF recovery rate), the concentration cannot be increased beyond the NF process's optimum recovery rate because the resulting increase in energy consumption will increase the OPEX cost of the final water. As a result, the determination of the optimum NF feed recovery rate must take into account the membrane replacement cost and the energy consumption.

Fig. 6 presents a comparison between the unit OPEX cost of water for the FDFO-NF, MF-RO, and UF-RO hybrid systems, given variations in the NF recovery rate. A simulation was carried out assuming $\mathrm{SOA}$ fertilizer as $\mathrm{DS}, \mathrm{NaCl}$ as FS (refer Fig. 2), $\mathrm{NaCl}$ and $\mathrm{SOA}$ rejection rates of FO and NF membranes of $90 \%$ based on our recent study [47]. The NF recovery rate was varied from $50 \%$ to $97 \%$. The OPEX cost of the FDFO process decreased rapidly with an increase in the NF recovery rates for both the CTA and TFC FO membranes and gradually increased above an $80 \%$ NF recovery rates. When NF is performed at a higher NF feed recovery rate, it produces a proportionately higher concentration of the recycled DS, which in turn increases the driving force of the FDFO process. This ultimately decreases the membrane area required and hence the unit OPEX cost of FO membrane replacement is reduced. However, operating the NF process at a higher recovery requires higher applied pressure which increases the energy cost of the NF process although the NF membrane replacement cost may slightly decrease.

- Considering the combined OPEX costs of the FDFO and NF processes, the optimum NF feed recovery rate for the FDFO-NF (CTA) hybrid system was observed to be about $89 \%$ with a unit OPEX cost of water of AUD $\$ 0.57 / \mathrm{m}^{3}$. The optimum NF feed recovery rate of the FDFO-NF (TFC) hybrid system, however, ranged between $75 \%$ and $91 \%$ with a unit OPEX cost of water at about AUD $\$ 0.40 / \mathrm{m}^{3}$. Even at the optimum NF feed recovery rate, the FDFO-NF (CTA) hybrid system remained less cost effective than conventional RO hybrid systems. Conversely, the FDFO-NF (TFC) hybrid system was 
found to be more cost-effective than the RO hybrid systems over a wide range of NF feed recovery rates $(75-91 \%)$. Increasing NF feed recovery rates above the optimum rate increases energy costs, and lowering it below the optimum rate significantly increases membrane replacement costs. For example, if NF in the FDFO-NF (CTA) hybrid system is performed at a lower feed recovery rate of $75 \%$, the unit OPEX cost of water increases to AUD $\$ 1.20 / \mathrm{m}^{3}$ from AUD $\$ 0.58 / \mathrm{m}^{3}$ at the optimum rate of $89 \%$. Likewise, the unit OPEX of the FDFO-NF (TFC) system increases to AUD $\$ 0.49 / \mathrm{m}^{3}$ (at $75 \%$ NF recovery rate) from AUD $\$ 0.41 / \mathrm{m}^{3}$ at the optimum recovery rate (at $84 \% \mathrm{NF}$ recovery rate). At this unit OPEX costs, the FDFO-NF hybrid system is not cost competitive compared to the conventional RO hybrid systems and the unit OPEX cost of water only increases if the NF process is performed above than the optimum recovery rates. This sensitivity analysis, therefore, shows that potential exists for making the FDFO-NF hybrid system more cost effective compared to conventional RO hybrid systems for the desalination of saline water. It has to be noted here that capital costs for a high-pressure RO hybrid system could be higher than those for a lower pressure FDFO-NF hybrid system due to the costs for high-pressure pumps, piping, valves, and fittings. This part would be considered as potential cost savings for the FDFO-NF hybrid system. 


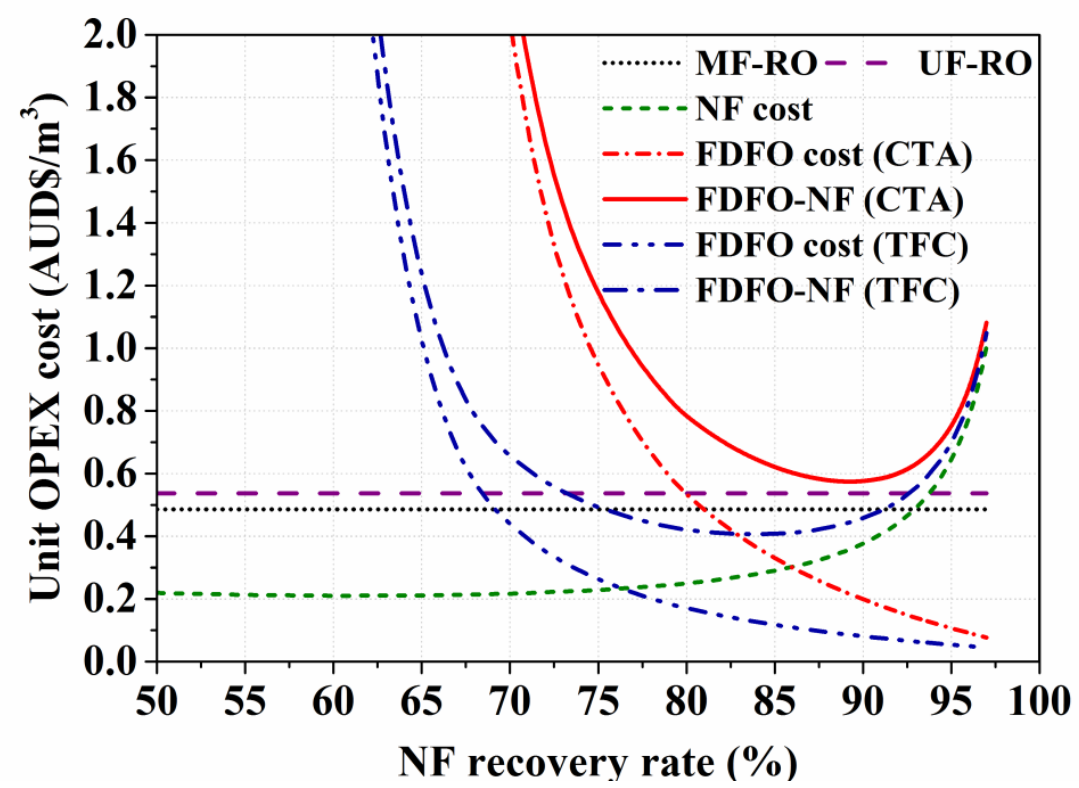

Fig. 6. Sensitivity analysis of FDFO-NF (CTA and TFC) OPEX costs as a function of NF process recovery rates. The FO module cost was assumed to be $\$ 1,250 /$ module in 2016, and the average FO water fluxes were estimated based on the closed-loop mass-balance simulation of the FDFO-NF hybrid system.

\section{Conclusions}

This study outlined the results of a comparative environmental life cycle assessment and economic analysis for desalination of mine impaired saline water for irrigation purpose. The FDFO-NF hybrid system was compared to conventional MF-RO and UF-RO hybrid systems with the following conclusions drawn:

- Environmental LCA results showed that, compared to conventional RO hybrid systems, the FDFO-NF hybrid system using TFC FO membrane had the lowest overall environmental impact in both energy consumption and use of chemical cleaners.

- The FDFO-NF hybrid system consumes less energy than the RO hybrid system in irrigation water production. The total energy consumption of the FDFO-NF hybrid system was estimated at $1.08 \mathrm{kWh} / \mathrm{m}^{3}$, which is $13.6 \%$ lower than the MF-RO system and $21 \%$ lower than the UF-RO hybrid system.

- The unit OPEX cost of producing FDFO-NF water using a TFC FO membrane was estimated at AUD $\$ 0.46 / \mathrm{m}^{3}$, which is cost effective when compared to the MF-RO hybrid 
system at AUD $\$ 0.49 / \mathrm{m}^{3}$ and the UF-RO hybrid system at AUD $\$ 0.54 / \mathrm{m}^{3}$. However, when using a CTA FO membrane, the FDFO-NF hybrid system had a per unit OPEX water cost of AUD $\$ 0.81 / \mathrm{m}^{3}$ which is not cost effective. The energy was found to be the highest cost component of the RO hybrid systems, whereas membrane replacement costs are the highest in the FDFO-NF hybrid systems.

- FDFO-NF with TFC membranes showed the lowest relative environmental impact compared to all other hybrid systems.

- The sensitivity analysis indicated that the FDFO-NF hybrid system using an 8040 CTA FO membrane module is only cost competitive when its module average water flux reaches $8 \mathrm{LMH}$ or, alternatively, if the cost of the CTA FO membrane could be reduced by about $60 \%$.

- The optimum feed recovery rate of the NF process using a TFC FO membrane was 75$92 \%$, which resulted in the lowest unit OPEX water at AUD $\$ 0.41 / \mathrm{m}^{3}$ at $84 \%$. At the optimum NF recovery rate of $89 \%$, the unit cost of water using a CTA FO membrane was AUD $\$ 0.57 / \mathrm{m}^{3}$ which is still not cost competitive compared to conventional RO hybrid systems.

- Results of this study clearly show that there are some positive potential of the FDFO-NF for the practical application if incorporating higher reverse flux selectivity FO membrane (i.e., TFC FO) and lowering the FO membrane module cost for the FO process. However, FO membrane studies at modular level are still limited and thus its detailed study including fouling behaviors and effective cleaning strategies needs to be further conducted. Based on this study, further study should focus on module arrangements and pressure behavior at modular level of the FO process in order to improve and obtain more accurate, reliable and realistic economic assessment of the FDFO-NF process. 


\section{Acknowledgements}

Funding for this research was also provided by Industrial Facilities \& Infrastructure Research

Program (code 17IFIP-B088091-04) by Ministry of Land, Infrastructure and Transport of Korean Government, King Abdullah University of Science and Technology (KAUST), Saudi Arabia, National Centre for Excellence in Desalination Australia (NCEDA), ARC Future Fellowship (FT140101208) and University of Technology Sydney (UTS) Chancellor's postdoctoral research fellowship.

\section{References}

1. Nicholas, A., Australian experience in water and energy footprints. Water Practice \& Technology, 2010. 5(4).

2. Thiruvenkatachari, R., M. Younes, and S. Su, Coal mine site investigation of wastewater quality in Australia. Desalination and Water Treatment, 2011. 32(1-3): p. 357-364.

3. Phuntsho, S., J.E. Kim, et al., Fertiliser drawn forward osmosis process: Pilot-scale desalination of mine impaired water for fertigation. Journal of Membrane Science, 2016. 508: p. 22-31.

4. $\quad$ Blandin, G., A.R. Verliefde, et al., Opportunities to reach economic sustainability in forward osmosis-reverse osmosis hybrids for seawater desalination. Desalination, 2015. 363: p. 26-36.

5. Ghaffour, N., T.M. Missimer, and G.L. Amy, Technical review and evaluation of the economics of water desalination: current and future challenges for better water supply sustainability. Desalination, 2013. 309: p. 197-207.

6. Subramani, A., M. Badruzzaman, et al., Energy minimization strategies and renewable energy utilization for desalination: A review. Water Research, 2011. 45(5): p. 1907-1920.

7. Phuntsho, S., H.K. Shon, et al., A novel low energy fertilizer driven forward osmosis desalination for direct fertigation: Evaluating the performance of fertilizer draw solutions. Journal of Membrane Science, 2011.375(1-2): p. 172-181.

8. Phuntsho, S., H.K. Shon, et al., Fertiliser drawn forward osmosis desalination: The concept, performance and limitations for fertigation. Reviews in Environmental Science and Bio/Technology, 2012 a.

9. Kim, J.E., S. Phuntsho, et al., Investigation of pilot-scale 8040 FO membrane module under different operating conditions for brackish water desalination. Desalination and Water Treatment, 2014. 53(10): p. 2782-2791.

10. Phuntsho, S., S. Sahebi, et al., Assessing the major factors affecting the performances of forward osmosis and its implications on the desalination process. Chemical Engineering Journal, 2013. 231(0): p. 484-496.

11. Chekli, L., J.E. Kim, et al., Fertilizer drawn forward osmosis process for sustainable water reuse to grow hydroponic lettuce using commercial nutrient solution. Separation and Purification Technology, 2017. 181: p. 18-28.

12. Kim, J., G. Blandin, et al., Practical considerations for operability of an 8" spiral wound forward osmosis module: Hydrodynamics, fouling behaviour and cleaning strategy. Desalination, 2017. 404: p. 249-258.

13. Coday, B.D., L. Miller-Robbie, et al., Life cycle and economic assessments of engineered osmosis and osmotic dilution for desalination of Haynesville shale pit water. Desalination, 2015. 369: p. 188-200. 
14. Hancock, N.T., N.D. Black, and T.Y. Cath, A comparative life cycle assessment of hybrid osmotic dilution desalination and established seawater desalination and wastewater reclamation processes. Water Research, 2012. 46(4): p. 1145-1154.

15. Arvanitoyannis, I.S., 3 - ISO 14040: Life Cycle Assessment (LCA) - Principles and Guidelines, in Waste Management for the Food Industries, I.S. Arvanitoyannis, Editor 2008, Academic Press: Amsterdam. p. 97-132.

16. Biswas, W.K., Life Cycle Assessment of Seawater Desalinization in Western Australia. World Academy of Science, Engineering \& Technology, 2009. 56: p. 369-375.

17. Valladares Linares, R., Z. Li, et al., Life cycle cost of a hybrid forward osmosis - low pressure reverse osmosis system for seawater desalination and wastewater recovery. Water Research, 2016. 88: p. 225-234.

18. Shahabi, M.P., A. McHugh, and G. Ho, Environmental and economic assessment of beach well intake versus open intake for seawater reverse osmosis desalination. Desalination, 2015. 357(0): p. 259-266.

19. PRé-Consultants, S., SimaPro software, 2008, SimaPro Version.

20. Grant, T., K.L. James, and S. Lundie, Alcas: Australian Lca Society. The International Journal of Life Cycle Assessment, 2001. 6(6): p. 323-324.

21. Frischknecht, R., N. Jungbluth, et al., The ecoinvent database: Overview and methodological framework (7 pp). The International Journal of Life Cycle Assessment, 2005. 10(1): p. 3-9.

22. Bonton, A., C. Bouchard, et al., Comparative life cycle assessment of water treatment plants. Desalination, 2012. 284(0): p. 42-54.

23. Tarnacki, K., M. Meneses, et al., Environmental assessment of desalination processes: Reverse osmosis and Memstill ${ }^{\circledR}$. Desalination, 2012. 296(0): p. 69-80.

24. AEMC, Final Report: 2013 Residential Electricity Price Trends. Australian Energy Market Commission (AEMC), 2013.

25. Zhou, J., V.W.C. Chang, and A.G. Fane, Life Cycle Assessment for desalination: A review on methodology feasibility and reliability. Water Research, 2014. 61(0): p. 210-223.

26. Moch, I., W.R. Querns, et al., WT Cost II modeling the capital and operating costs of thermal desalination processes utilizing a recently developed computer program that evaluates membrane desalting, electrodialysis, and ion exchange plants : case study for a seawater 20million-gallon-per-day (MGD) hybrid system involving 10-MGD multistage flash distillation plus 10-MGD reverse osmosis2008, Denver, Colo.; Springfield, Va.: U.S. Dept. of the Interior, Bureau of Reclamation, Technical Service Center, Water and Environmental Services Division, Water Treatment Engineering Research Team ; Available through the National Technical Information Service.

27. Bigbrandwater. Bigbrandwater. 2016; Available from: http://www.bigbrandwater.com/filmtec1.html.

28. Holloway, R.W., L. Miller-Robbie, et al., Life-cycle assessment of two potable water reuse technologies: $M F / R O / U V-A O P$ treatment and hybrid osmotic membrane bioreactors. Journal of Membrane Science, 2016. 507: p. 165-178.

29. Pryshlakivsky, J. and C. Searcy, Fifteen years of ISO 14040: a review. Journal of Cleaner Production, 2013. 57(0): p. 115-123.

30. Liyanaarachchi, S., V. Jegatheesan, et al., Mass balance for a novel RO/FO hybrid system in seawater desalination. Journal of Membrane Science, 2016. 501: p. 199-208.

31. Deshmukh, A., N.Y. Yip, et al., Desalination by forward osmosis: Identifying performance limiting Parameters through module-scale modeling. Journal of Membrane Science, 2015. 491: p. 159-167.

32. Zaviska, F. and L. Zou, Using modelling approach to validate a bench scale forward osmosis pre-treatment process for desalination. Desalination, 2014. 350(0): p. 1-13.

33. Sim, V.S.T., Q. She, et al., Strategic Co-Location in a Hybrid Process Involving Desalination and Pressure Retarded Osmosis (PRO). Membranes, 2013.

34. Masters, G.M., Introduction to environmental engineering and Science Prentice Hall. Upper Saddle River, 1991.

35. Watson, I.C., O. Morin, and L. Henthorne, Desalting handbook for planners. Desalination Research and Development Program Report, 2003. 72. 
36. Shaffer, D.L., N.Y. Yip, et al., Seawater desalination for agriculture by integrated forward and reverse osmosis: Improved product water quality for potentially less energy. Journal of Membrane Science, 2012. 415: p. 1-8.

37. Kim, J.E., S. Phuntsho, and H.K. Shon, Pilot-scale nanofiltration system as post-treatment for fertilizer-drawn forward osmosis desalination for direct fertigation. Desalination and Water Treatment, 2013(ahead-of-print): p. 1-9.

38. Wilf, M. Fundamentals of RO-NF technology. in Paper presented at International Conference on Desalination Costing, Limassol. 2004.

39. Altaee, A. and G. Zaragoza, A conceptual design of low fouling and high recovery FO-MSF desalination plant. Desalination, 2014. 343(0): p. 2-7.

40. Lotfi, F., L. Chekli, et al., Understanding the possible underlying mechanisms for low fouling tendency of the forward osmosis and pressure assisted osmosis processes. Desalination, 2017. In Press.

41. Ang, W.S., S. Lee, and M. Elimelech, Chemical and physical aspects of cleaning of organicfouled reverse osmosis membranes. Journal of Membrane Science, 2006. 272(1): p. 198-210.

42. Yip, N.Y., A. Tiraferri, et al., High Performance Thin-Film Composite Forward Osmosis Membrane. Environmental Science \& Technology, 2010. 44(10): p. 3812-3818.

43. Duong, P.H.H. and T.-S. Chung, Application of thin film composite membranes with forward osmosis technology for the separation of emulsified oil-water. Journal of Membrane Science, 2014. 452(0): p. 117-126.

44. Tiraferri, A., N.Y. Yip, et al., Relating performance of thin-film composite forward osmosis membranes to support layer formation and structure. Journal of Membrane Science, 2011. 367(1-2): p. 340-352.

45. Han, G., B. Zhao, et al., High performance thin-film composite membranes with meshreinforced hydrophilic sulfonated polyphenylenesulfone (sPPSU) substrates for osmotically driven processes. Journal of Membrane Science, 2016. 502: p. 84-93.

46. Han, G., T.-S. Chung, et al., Thin-film composite forward osmosis membranes with novel hydrophilic supports for desalination. Journal of Membrane Science, 2012. 423: p. 543-555.

47. Phuntsho, S., J.E. Kim, et al., A closed-loop forward osmosis-nanofiltration hybrid system: Understanding process implications through full-scale simulation. Desalination, 2017. 


\section{Supplementary Information}

\section{Environmental and economic impacts of fertilizer drawn forward osmosis and nanofiltration hybrid system}

Jung Eun Kim ${ }^{\mathrm{a}}$, Sherub Phuntsho ${ }^{\mathrm{a}}$, Laura Cheklia, Seungkwan Hong ${ }^{\mathrm{b}}$, Noreddine Ghaffour ${ }^{\mathrm{c}}$, TorOve Leiknes ${ }^{\mathrm{c}}$, Joon Yong Choid ${ }^{\mathrm{d}}$, Ho Kyong Shon ${ }^{\mathrm{a} *}$

a Centre for Technology in Water and Wastewater, School of Civil and Environmental Engineering, University of Technology, Sydney (UTS), Broadway, NSW 2007, Australia

b School of Civil, Environmental \& Architectural Engineering, Korea University, 1, 5-ka, Anam-Dong, Sungbuk-Gu, Seoul 136-713, Republic of Korea

${ }^{c}$ King Abdullah University of Science and Technology (KAUST), Water Desalination and Reuse Center (WDRC), Biological and Environmental Sciences \& Engineering Division (BESE), Thuwal, 23955-6900, Saudi Arabia

d Hyorim Industries Inc., Yatap-dong, Bundang-gu, Seongnam-city, 513-2, Gyeonggi-do, Republic of Korea

*Corresponding authors: Email: Hokyong.Shon-1@uts.edu.au; $\underline{\text { Sherub.Phuntsho@uts.edu.au }}$ 
Table S1 Characterisation of mine impaired feed water for all hybrid systems and NF feed and permeate water for the NF process in the FDFO-NF hybrid system [1].

\begin{tabular}{|c|c|c|c|c|}
\hline Parameters & Unit & $\begin{array}{c}\text { Saline feed water }{ }^{2} \\
\text { (Average) }\end{array}$ & $\begin{array}{c}\text { Diluted DS } \\
\text { (Average) }\end{array}$ & $\begin{array}{c}\text { Final product } \\
\text { water (Average) }\end{array}$ \\
\hline $\mathrm{pH}$ & - & 7.8 & 7.7 & 8.15 \\
\hline $\begin{array}{l}\text { Conductivity } \\
\text { (EC) }\end{array}$ & $\mathrm{mS} / \mathrm{cm}$ & 5.40 & 13.5 & 0.81 \\
\hline $\begin{array}{l}\text { Total Dissolved } \\
\text { Solids (TDS) }\end{array}$ & $\mathrm{mg} / \mathrm{L}$ & 2,491 & 7,604 & $\sim 266$ \\
\hline Turbidity & NTU & 1.0 & 0.25 & 0.1 \\
\hline Orthophosphate & $\mathrm{mg} / \mathrm{L} \mathrm{P}$ & $<0.009$ & $\mathrm{~N} / \mathrm{D}$ & N/D \\
\hline Nitrate & $\mathrm{mg} / \mathrm{L} \mathrm{N}$ & $<0.005$ & $\mathrm{~N} / \mathrm{D}$ & N/D \\
\hline Nitrite & $\mathrm{mg} / \mathrm{L} \mathrm{N}$ & N/D & N/D & N/D \\
\hline Ammonia & $\mathrm{mg} / \mathrm{L} \mathrm{N}$ & 12.0 & 1,897 & 75 \\
\hline Sodium & $\mathrm{mg} / \mathrm{L}$ & 812.0 & 231 & 10 \\
\hline Potassium & $\mathrm{mg} / \mathrm{L}$ & 7.0 & 1.2 & 0.2 \\
\hline Calcium & $\mathrm{mg} / \mathrm{L}$ & 48.0 & 1.5 & 0.15 \\
\hline Magnesium & $\mathrm{mg} / \mathrm{L}$ & 22.0 & 0.5 & 0.2 \\
\hline Chloride & $\mathrm{mg} / \mathrm{L}$ & 983.0 & 185 & 15 \\
\hline Sulphate & $\mathrm{mg} / \mathrm{L} \mathrm{SO}_{4}{ }^{2-}$ & 607.0 & 5288.0 & 165 \\
\hline SAR & - & 24.5 & 42.0 & 4.0 \\
\hline $\begin{array}{l}\text { Osmotic } \\
\text { pressure }^{1}\end{array}$ & bar & 1.66 & 3.64 & - \\
\hline
\end{tabular}

${ }^{1}$ ROSA software

${ }^{2}$ It was assumed that the feed water concentration for all hybrid system is similar to the feed water used for the FDFO process in previous study [1].

${ }^{3}$ Diluted draw solution (DDS) in the FDFO process was treated by the NF process to meet a suitable water quality for direct irrigation. The average SAR value 4.0 was still lower and within the acceptable values of less than 6 for irrigation [1]. 
Table S2 Environmental impact categories used in LCIA [2-5].

Impact category

Global warming (GW)

Eutrophication (EP)

Ozone depletion (OD)

Fossil fuel and mineral resource (FMR)

Eco-toxicity (ET)

Human toxicity (HT)

\section{Description}

Effect of greenhouse gases on climate change based on the Intergovernmental Panel on Climate Change Effect of excessive levels of macronutrients in the environment caused by emissions of nutrients to air, water, and soil Ozone depletion potential of different gases in terms of chlorinated fluorocarbon 11 equivalent

Effect of extraction of minerals and fossil fuels as a mass of antimony equivalent Resulting from emissions of toxic substances to air, water, and soil. Effect of chemical substance on human health 


\section{S1. FO flux modelling}

A sensitivity analysis was performed to provide a more realistic economic and environmental life cycle analysis on the FDFO-NF hybrid desalination process compared to other desalination hybrid systems. To validate the model equations used in this study, water flux was measured from feed water with an osmotic pressure of 1.66 bar and ammonium sulphate draw solution concentrations of 1, 2, and $3 \mathrm{M}$. As shown in Fig. S1, the experimental and modelled results show good agreement with the governing Equation.3 in Table S3.

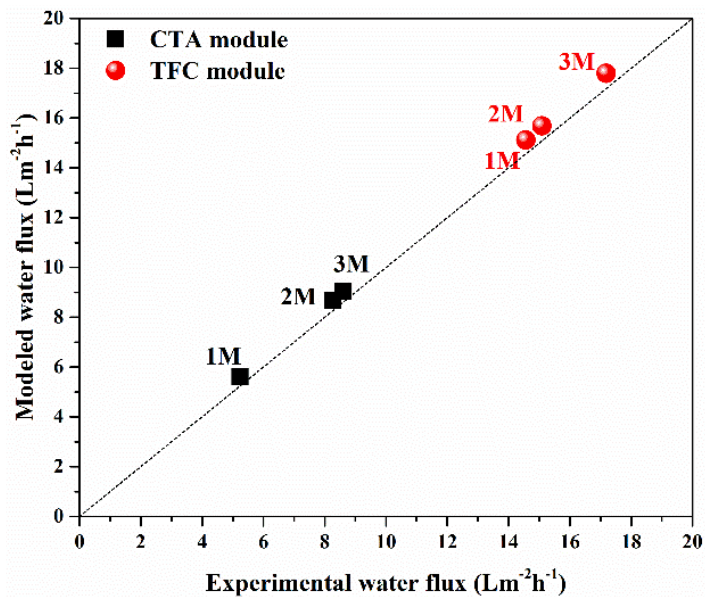

Fig. S1. Modelled water flux as a function of experimental water flux. The modelled water flux was calculated using Equation. 3 in Table S3. Feed concentration was constant at 1.66 bars (feed water was converted to the concentration of $\mathrm{NaCl}$ and calculated the osmotic pressure using OLI software). The draw solution concentration varied. The feed rate was 70 $\mathrm{L} / \mathrm{min}$, the draw flow rate was $7 \mathrm{~L} / \mathrm{min}$, and temperature was $25^{\circ} \mathrm{C}$. 
Table S3. Flux modelling adapted in this study for FO full-scale simulation

\section{Model}

A module-scale model governed by solutiondiffusion [6-8]:

\section{Model equations}

$$
\text { Eq.1 Water recovery, } \mathrm{R}=\frac{\mathrm{Q}_{\mathrm{p}}}{\mathrm{Q}_{\mathrm{F} 0}}
$$

Eq.2 Solute permeability coefficient, $B=\gamma \mathrm{A}^{3}$

$$
\text { (Constant value, } \gamma=0.0133 L^{-2} m^{4} h^{2} \text { bar }^{3} \text { ) }
$$

Eq.3 Water flux, $J_{W}=\frac{A\left[\pi_{D, b} \exp \left(-\frac{J_{W} S}{D}\right)-\pi_{F, b} \exp \left(\frac{J_{W}}{\mathrm{k}_{\mathrm{F}}}\right)\right]}{1+\frac{\mathrm{B}}{J_{\mathrm{W}}}\left[\exp \left(\frac{\mathrm{J}_{\mathrm{W}}}{\mathrm{k}_{\mathrm{F}}}\right)-\exp \left(-\frac{J_{\mathrm{W}} \mathrm{S}}{\mathrm{D}}\right)\right]}$

Eq.4 Mass transfer coefficient, $\mathrm{k}_{\mathrm{F}}=\frac{\mathrm{Sh}_{\mathrm{F}}}{\mathrm{D}_{\mathrm{h}}}$

Eq.5 Structural parameter, $S=K_{D} D=\frac{t_{s} \cdot \tau}{\varepsilon}$

Eq.6 Resistance to solute diffusion in the membrane support layer

$$
\mathrm{K}_{\mathrm{D}}=\left(\frac{1}{\mathrm{~J}_{\mathrm{w}}}\right) \ln \frac{\mathrm{B}+\mathrm{A} \pi_{\mathrm{D}, \mathrm{b}}}{\mathrm{B}+\mathrm{J}_{\mathrm{w}}+\mathrm{A} \pi_{\mathrm{F}, \mathrm{m}}}
$$

Eq.7 Solute flux, $J_{S}=\frac{B\left[C_{D, b} \exp \left(-\frac{J_{W} S}{D}\right)-C_{F, b} \exp \left(\frac{J_{W}}{k_{F}}\right)\right]}{1+\frac{B}{J_{W}}\left[\exp \left(\frac{J_{W}}{k_{F}}\right)-\exp \left(-\frac{J_{W} S}{D}\right)\right]}$

$\mathrm{Q}_{\mathrm{P}}=$ water permeation across the membrnae, $\mathrm{L} / \mathrm{min}$

$\mathrm{Q}_{\mathrm{F} 0}$ and $\mathrm{Q}_{\mathrm{D} 0}=$ initial feed and draw flow rates, respectively, $\mathrm{L} / \mathrm{min}$

$\mathrm{C}_{\mathrm{F} 0}$ and $\mathrm{C}_{\mathrm{D} 0}=$ inlet feed and draw concetnrations, respectively, $\mathrm{M}$

$\mathrm{C}_{\mathrm{Fb}}$ and $\mathrm{C}_{\mathrm{Db}}=$ bulk feed and draw concetnrations, respectively, $\mathrm{M}$

$\mathrm{A}=$ membrane water permeability coefficient, $\mathrm{Lm}^{-2} \mathrm{~h}^{-1} \mathrm{bar}^{-1}$

$\pi_{\mathrm{F}, \mathrm{b}}$ and $\pi_{\mathrm{D}, \mathrm{b}}=$ bulk feed and draw osmotic pressure, respectively, bar

$\pi_{\mathrm{F}, \mathrm{m}}$ and $\pi_{\mathrm{D}, \mathrm{m}}=$ feed and draw osmotic pressure on the active layer and the support layer, respectively, bar

Sherwood number, $\mathrm{Sh}=1.85\left(\operatorname{Re} \mathrm{Sc} \frac{\mathrm{d}_{\mathrm{h}}}{\mathrm{L}}\right)^{0.33}$, Laminar flow

Sherwood number, $\mathrm{Sh}=0.04 \mathrm{Re}^{0.75} \mathrm{Sc}^{0.33}$, Turbulent flow

Schmidt number, $\mathrm{Sc}=\frac{\mu}{\rho \mathrm{D}_{\mathrm{F}}}$

$\mu=$ dynamic viscosity

$\rho=$ solution density

$\mathrm{D}_{\mathrm{D}}=$ diffusion coefficient of the draw solute, $\mathrm{m}^{2} / \mathrm{s}$

$\mathrm{D}_{\mathrm{F}}=$ diffusion coefficient of the feed solute, $\mathrm{m}^{2} / \mathrm{s}$

$D_{h}=$ hydraulic diameter of the feed channel, $m$ 
Table S4 Input parameters used for FO flux estimation based on the pilot operation data.

\section{Parameters Unit Values}

Membrane material CTA / TFC

Pure water permeability, A

Salt permeability, B

$\mathrm{Lm}^{-2} \mathrm{~h}^{-1} \mathrm{bar}^{-1}$

$1.02 / 2.02$

Effective membrane module area $\mathrm{Lm}^{-2} \mathrm{~h}^{-1}$

$0.46 / 0.67$

$$
\mathrm{m}^{2}
$$

$11.2 / 15.3$

FS, mine impaired water concentration $(\approx \mathrm{NaCl})$ $\mathrm{M}$ 0.06 DS, $\left(\mathrm{NH}_{2}\right)_{4} \mathrm{SO}_{4}$ or SOA

$\mathrm{M} \quad 1.89$


Table S5 Operational phase of life cycle inventories (LCI) for all hybrid processes.

\begin{tabular}{|c|c|c|c|c|}
\hline $\begin{array}{c}\text { Unit } \\
\text { process }\end{array}$ & Value & Unit & Design assumptions & Methods \\
\hline \multicolumn{5}{|c|}{ Chemical use for cleaning } \\
\hline \multirow{4}{*}{$\begin{array}{l}\text { MF-RO } \\
\text { UF-RO }\end{array}$} & $\begin{array}{c}\text { Sodium } \\
\text { hypochlorite } \\
\text { (NaOCl): } \\
1.22 \mathrm{E}-4\end{array}$ & $\mathrm{~kg} / \mathrm{m}^{3}$ & $\begin{array}{l}\text { - Design dosage rate: } \\
200 \mathrm{mg} / \mathrm{L}\end{array}$ & Literature [9-11] \\
\hline & $\begin{array}{l}\text { Hydrochloric } \\
\text { acid }(\mathrm{HCl}): \\
1.59 \mathrm{E}-03\end{array}$ & $\mathrm{~kg} / \mathrm{m}^{3}$ & \multirow{2}{*}{ - Cleaning chemicals } & \multirow[t]{2}{*}{$\begin{array}{l}\text { Literature } 6 \text { weeks }(= \\
9 / \text { year })[12,13]\end{array}$} \\
\hline & $\begin{array}{c}\text { Caustic soda } \\
(\mathrm{NaOH}) \\
: 5.26 \mathrm{E}-04 \\
\end{array}$ & $\mathrm{~kg} / \mathrm{m}^{3}$ & & \\
\hline & $\begin{array}{l}\text { Sodium tri- } \\
\text { phosphate } \\
\left(\mathrm{Na}_{5} \mathrm{P}_{3} \mathrm{O}_{10}\right) \\
: 3.31 \mathrm{E}-05\end{array}$ & $\mathrm{~kg} / \mathrm{m}^{3}$ & $\begin{array}{l}\text { - Anti-scalent dosage } \\
\text { rate: } 2 \mathrm{mg} / \mathrm{L}\end{array}$ & Literature $[10,12]$ \\
\hline \multirow{2}{*}{ NF } & $\begin{array}{l}\text { Hydrochloric } \\
\text { acid }(\mathrm{HCl}): \\
4.98 \mathrm{E}-05\end{array}$ & $\mathrm{~kg} / \mathrm{m}^{3}$ & \multirow{2}{*}{ - Cleaning chemicals } & \multirow[t]{2}{*}{$\begin{array}{l}\text { Real operation data: } \\
\text { 1/year [1] }\end{array}$} \\
\hline & $\begin{array}{l}\text { Caustic soda } \\
(\mathrm{NaOH}): \\
1.64 \mathrm{E}-05 \\
\end{array}$ & $\mathrm{~kg} / \mathrm{m}^{3}$ & & \\
\hline \multicolumn{5}{|c|}{ Membrane materials } \\
\hline \multirow{3}{*}{$\begin{array}{l}\text { MF } \\
\text { membrane }\end{array}$} & $3.42 \mathrm{E}-02$ & $\mathrm{~kg} / \mathrm{m}^{3}$ & $\begin{array}{ll} & \text { Polypropylene (PP): } \\
& \text { production of MF fibre }\end{array}$ & \multirow[t]{6}{*}{$\begin{array}{l}\text { Literature }[14,15]+ \\
\text { Assumptions }\end{array}$} \\
\hline & $3.79 \mathrm{E}-02$ & $\mathrm{~kg} / \mathrm{m}^{3}$ & $\begin{array}{l}\text { Polyurethane (PU): } \\
\text { potting of the module. }\end{array}$ & \\
\hline & $2.52 \mathrm{E}-06$ & $\mathrm{~kg} / \mathrm{m}^{3}$ & $\begin{array}{l}\text { Polyvinylchloride } \\
\text { (PVC): membrane } \\
\text { housing }\end{array}$ & \\
\hline \multirow{3}{*}{$\begin{array}{l}\text { UF } \\
\text { membrane }\end{array}$} & $3.59 \mathrm{E}-02$ & $\mathrm{~kg} / \mathrm{m}^{3}$ & $\begin{array}{l}\text { Polypropylene (PP): } \\
\text { production of UF fibre. }\end{array}$ & \\
\hline & $3.98 \mathrm{E}-02$ & $\mathrm{~kg} / \mathrm{m}^{3}$ & $\begin{array}{l}\text { Polyurethane (PU) is } \\
\text { used for potting of the } \\
\text { module. }\end{array}$ & \\
\hline & $2.65 \mathrm{E}-06$ & $\mathrm{~kg} / \mathrm{m}^{3}$ & $\begin{array}{l}\text { Polyvinylchloride } \\
\text { (PVC): membrane } \\
\text { housing }\end{array}$ & \\
\hline \multirow{4}{*}{$\begin{array}{l}\text { RO } \\
\text { membrane }\end{array}$} & $1.24 \mathrm{E}-03$ & $\mathrm{~kg} / \mathrm{m}^{3}$ & $\begin{array}{l}\text { Polyamide (PA): } \\
\text { production of RO fibre }\end{array}$ & \multirow[t]{4}{*}{$\begin{array}{l}\text { Literature }[2,13,16]+ \\
\text { Assumptions }\end{array}$} \\
\hline & $1.71 \mathrm{E}-06$ & $\mathrm{~kg} / \mathrm{m}^{3}$ & $\begin{array}{l}\text { Epoxy resin (Glue): } \\
\text { gluing the membrane } \\
\text { sheet. }\end{array}$ & \\
\hline & $3.47 \mathrm{E}-03$ & $\mathrm{~kg} / \mathrm{m}^{3}$ & $\begin{array}{l}\text { Polyethylene (PE): } \\
\text { membrane channel } \\
\text { spacer material. }\end{array}$ & \\
\hline & 3.32E-04 & $\mathrm{kg} / \mathrm{m}^{3}$ & - Polyvinylchloride & \\
\hline
\end{tabular}




\begin{tabular}{|c|c|c|c|c|}
\hline & & & $\begin{array}{l}\text { (PVC) is central } \\
\text { collection tube. }\end{array}$ & \\
\hline & $3.70 \mathrm{E}-03$ & $\mathrm{~kg} / \mathrm{m}^{3}$ & $\begin{array}{l}\text { - Fibre glass plastic } \\
\text { (FRP): membrane } \\
\text { housing. }\end{array}$ & \\
\hline \multirow{10}{*}{$\begin{array}{l}\text { FO (CTA) } \\
\text { membrane }\end{array}$} & $5.83 \mathrm{E}-04$ & $\mathrm{~kg} / \mathrm{m}^{3}$ & $\begin{array}{l}\text { Cellulose acetate: } \\
\text { membrane active } \\
\text { layer. }\end{array}$ & \multirow[t]{14}{*}{$\begin{array}{l}\text { Literature }[2,13,17]+ \\
\text { Assumptions }+ \text { real } \\
\text { operation data }[1]\end{array}$} \\
\hline & $3.01 \mathrm{E}-03$ & $\mathrm{~kg} / \mathrm{m}^{3}$ & $\begin{array}{l}\text { Polyester (PET): } \\
\text { production of FO fibre } \\
\text { (support layer). }\end{array}$ & \\
\hline & $4.57 \mathrm{E}-02$ & $\mathrm{~kg} / \mathrm{m}^{3}$ & $\begin{array}{l}\text { Epoxy resin: gluing } \\
\text { the membrane sheet. }\end{array}$ & \\
\hline & $6.60 \mathrm{E}-04$ & $\mathrm{~kg} / \mathrm{m}^{3}$ & $\begin{array}{l}\text { Suspension } \\
\text { polymerised } \\
\text { polyvinylchloride } \\
\text { (PVC): sealant tape of } \\
\text { the module. }\end{array}$ & \\
\hline & $2.16 \mathrm{E}-03$ & $\mathrm{~kg} / \mathrm{m}^{3}$ & $\begin{array}{l}\text { Polypropylene (PP): } \\
\text { filament tape of the } \\
\text { module. }\end{array}$ & \\
\hline & $1.75 \mathrm{E}-02$ & $\mathrm{~kg} / \mathrm{m}^{3}$ & $\begin{array}{l}\text { Polyethylene (PE): } \\
\text { membrane feed } \\
\text { channel spacer } \\
\text { material. }\end{array}$ & \\
\hline & $1.09 \mathrm{E}-02$ & $\mathrm{~kg} / \mathrm{m}^{3}$ & $\begin{array}{l}\text { Polyester (PET): } \\
\text { membrane draw } \\
\text { channel spacer } \\
\text { material. }\end{array}$ & \\
\hline & $3.62 \mathrm{E}-03$ & $\mathrm{~kg} / \mathrm{m}^{3}$ & $\begin{array}{l}\text { ABS: centre core flow } \\
\text { adapters and anti- } \\
\text { telescoping device. }\end{array}$ & \\
\hline & $6.14 \mathrm{E}-03$ & $\mathrm{~kg} / \mathrm{m}^{3}$ & $\begin{array}{l}\text { Polyvinylchloride } \\
\text { (PVC): central } \\
\text { collection tube. }\end{array}$ & \\
\hline & $2.90 \mathrm{E}-02$ & $\mathrm{~kg} / \mathrm{m}^{3}$ & $\begin{array}{l}\text { Polyvinylchloride } \\
\text { (PVC): membrane } \\
\text { housing. }\end{array}$ & \\
\hline \multirow{4}{*}{$\begin{array}{l}\text { FO (TFC) } \\
\text { membrane }\end{array}$} & $7.54 \mathrm{E}-04$ & $\mathrm{~kg} / \mathrm{m}^{3}$ & $\begin{array}{l}\text { Polyamide (PA): } \\
\text { membrane active } \\
\text { layer. }\end{array}$ & \\
\hline & $3.77 \mathrm{E}-03$ & $\mathrm{~kg} / \mathrm{m}^{3}$ & $\begin{array}{l}\text { Polysulfone: } \\
\text { membrane support } \\
\text { layer. }\end{array}$ & \\
\hline & $1.37 \mathrm{E}-02$ & $\mathrm{~kg} / \mathrm{m}^{3}$ & $\begin{array}{l}\text { - Epoxy resin: gluing } \\
\text { the membrane sheet. }\end{array}$ & \\
\hline & $1.45 \mathrm{E}-04$ & $\mathrm{~kg} / \mathrm{m}^{3}$ & $\begin{array}{l}\text { Suspension } \\
\text { polymerised } \\
\text { polyvinylchloride }\end{array}$ & \\
\hline
\end{tabular}




\begin{tabular}{|c|c|c|c|c|}
\hline & & & $\begin{array}{l}\text { (PVC): sealant tape of } \\
\text { the module. }\end{array}$ & \\
\hline & 5.94E-05 & $\mathrm{kg} / \mathrm{m}^{3}$ & $\begin{array}{l}\text { Polypropylene (PP): } \\
\text { filament tape of the } \\
\text { module. }\end{array}$ & \\
\hline & $5.24 \mathrm{E}-03$ & $\mathrm{~kg} / \mathrm{m}^{3}$ & $\begin{array}{l}\text { Polyethylene }(\mathrm{PE}) \text { : } \\
\text { membrane feed } \\
\text { channel spacer } \\
\text { material. }\end{array}$ & \\
\hline & $3.26 \mathrm{E}-03$ & $\mathrm{~kg} / \mathrm{m}^{3}$ & $\begin{array}{l}\text { Polyester (PET): } \\
\text { membrane draw } \\
\text { channel spacer } \\
\text { material. }\end{array}$ & \\
\hline & $7.96 \mathrm{E}-04$ & $\mathrm{~kg} / \mathrm{m}^{3}$ & $\begin{array}{l}\text { ABS: centre core flow } \\
\text { adapters and anti- } \\
\text { telescoping device. }\end{array}$ & \\
\hline & $1.35 \mathrm{E}-03$ & $\mathrm{~kg} / \mathrm{m}^{3}$ & 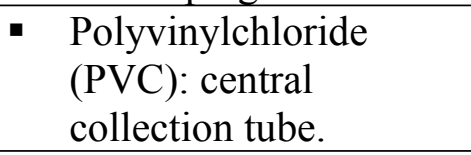 & \\
\hline & $6.37 \mathrm{E}-03$ & $\mathrm{~kg} / \mathrm{m}^{3}$ & $\begin{array}{l}\text { - Polyvinylchloride } \\
\text { (PVC): membrane } \\
\text { housing. }\end{array}$ & \\
\hline \multirow{6}{*}{$\begin{array}{l}\mathrm{NF} \\
\text { membrane }\end{array}$} & $3.18 \mathrm{E}-05$ & $\mathrm{~kg} / \mathrm{m}^{3}$ & $\begin{array}{l}\text { Polyamide (PA): } \\
\text { production of NF fibre. }\end{array}$ & \multirow[t]{6}{*}{$\begin{array}{l}\text { Literature }[13,16]+ \\
\text { Assumptions }\end{array}$} \\
\hline & $7.96 \mathrm{E}-06$ & $\mathrm{~kg} / \mathrm{m}^{3}$ & $\begin{array}{l}\text { Polysulfone: } \\
\text { membrane support } \\
\text { layer. }\end{array}$ & \\
\hline & $5.23 \mathrm{E}-05$ & $\mathrm{~kg} / \mathrm{m}^{3}$ & $\begin{array}{l}\text { - Epoxy resin: gluing } \\
\text { the membrane sheet. }\end{array}$ & \\
\hline & $1.62 \mathrm{E}-04$ & $\mathrm{~kg} / \mathrm{m}^{3}$ & $\begin{array}{l}\text { - Polyethylene (PE): } \\
\text { membrane channel } \\
\text { spacer material. }\end{array}$ & \\
\hline & 4.63E-05 & $\mathrm{kg} / \mathrm{m}^{3}$ & $\begin{array}{ll}\text { PVC } \\
\text { (polyvinylchloride): } \\
\text { central collection tube. }\end{array}$ & \\
\hline & $3.21 \mathrm{E}-03$ & $\mathrm{~kg} / \mathrm{m}^{3}$ & $\begin{array}{l}\text { Fibre glass plastic } \\
\text { (FRP): membrane } \\
\text { housing. }\end{array}$ & \\
\hline
\end{tabular}




\section{References}

1. Phuntsho, S., et al., Fertiliser drawn forward osmosis process: Pilot-scale desalination of mine impaired water for fertigation. Journal of Membrane Science, 2016. 508: p. 22-31.

2. Hancock, N.T., N.D. Black, and T.Y. Cath, A comparative life cycle assessment of hybrid osmotic dilution desalination and established seawater desalination and wastewater reclamation processes. Water Research, 2012. 46(4): p. 1145-1154.

3. Bengtsson, J. and N. Howard, A Life Cycle Impact Assessment Method for Use in Australia-Classification, Characterisation and Research Needs. 2010.

4. PRé-Consultants, S., SimaPro software, 2008, SimaPro Version.

5. Fritzmann, C., et al., State-of-the-art of reverse osmosis desalination. Desalination, 2007. 216(1): p. 1-76.

6. Deshmukh, A., et al., Desalination by forward osmosis: Identifying performance limiting Parameters through module-scale modeling. Journal of Membrane Science, 2015. 491: p. 159-167.

7. Tiraferri, A., et al., A method for the simultaneous determination of transport and structural parameters of forward osmosis membranes. Journal of Membrane Science, 2013. 444(0): p. 523-538.

8. Phuntsho, S., et al., Osmotic equilibrium in the forward osmosis process: Modelling, experiments and implications for process performance. Journal of Membrane Science, 2014. 453(0): p. 240-252.

9. Moch, I., et al., WT Cost II modeling the capital and operating costs of thermal desalination processes utilizing a recently developed computer program that evaluates membrane desalting, electrodialysis, and ion exchange plants : case study for a seawater 20-million-gallon-per-day (MGD) hybrid system involving 10-MGD multistage flash distillation plus 10-MGD reverse osmosis2008, Denver, Colo.; Springfield, Va.: U.S. Dept. of the Interior, Bureau of Reclamation, Technical Service Center, Water and Environmental Services Division, Water Treatment Engineering Research Team ; Available through the National Technical Information Service.

10. Shahabi, M.P., A. McHugh, and G. Ho, Environmental and economic assessment of beach well intake versus open intake for seawater reverse osmosis desalination. Desalination, 2015. 357(0): p. 259-266.

11. Pickering, K.D. and M.R. Wiesner, Cost model for low-pressure membrane filtration. Journal of Environmental Engineering, 1993. 119(5): p. 772-797.

12. Corral, A.F. and U. Yenal, Reverse Osmosis Treatment of Central Arizona Project Water-Brine Minimization Via Vibratory Shear-enhanced Processing. 1932.

13. Coday, B.D., et al., Life cycle and economic assessments of engineered osmosis and osmotic dilution for desalination of Haynesville shale pit water. Desalination, 2015. 369: p. 188-200.

14. Cheryan, M., Ultrafiltration and microfiltration handbook1998: CRC press.

15. Tangsubkul, N., et al., Environmental life cycle assessment of the microfiltration process. Journal of Membrane Science, 2006. 284(1-2): p. 214-226.

16. Bonton, A., et al., Comparative life cycle assessment of water treatment plants. Desalination, 2012. 284(0): p. 42-54.

17. Sim, V.S.T., et al., Strategic Co-Location in a Hybrid Process Involving Desalination and Pressure Retarded Osmosis (PRO). Membranes, 2013. 


\section{Research highlights}

- The FDFO-NF(TFC) hybrid system has lower environmental impact than RO hybrid system

- The FDFO-NF hybrid system consumes 35\% less energy than the UF-RO hybrid system

- The unit OPEX cost of FDFO-NF (TFC) system is 26\% lower than UF-RO hybrid system

- Improving flux and lowering the cost of the CTA FO membrane can make the FDFO-NF cost effective 